García-Delgado, C.; Barba, V.; Marín-Benito, J.M., Igual, J.M.; Sánchez-Martín, M.J.; RodríguezCruz, M.S. 2019. Influence of different agricultural management practices on soil microbial community over dissipation time of two herbicides. Science of the Total Environment, 646: 1478-1488.

\title{
INFLUENCE OF DIFFERENT AGRICULTURAL MANAGEMENT PRACTICES ON SOIL MICROBIAL COMMUNITY OVER DISSIPATION TIME OF TWO HERBICIDES
}

Carlos García-Delgado, Víctor Barba-Vicente, Jesús M. Marín-Benito, J. Mariano Igual, María J. Sánchez-Martín, M. Sonia Rodríguez-Cruz*

Institute of Natural Resources and Agrobiology of Salamanca (IRNASA-CSIC), 40-52 Cordel de Merinas, 37008 Salamanca, Spain

* Corresponding author:

msonia.rodriguez@irnasa.csic.es (M. Sonia Rodríguez-Cruz) 


\section{ABSTRACT}

2 Soil microbiology could be affected by the presence of pesticide residues during

3 intensive farming, potentially threatening the soil environment. The aim here was to

4 assess the dissipation of the herbicides triasulfuron and prosulfocarb, applied as a

5 combined commercial formulation, and the changes in soil microbial communities

6 (through the profile of phospholipid fatty acids (PLFAs) extracted from the soil) during

7 the dissipation time of the herbicides under field conditions. The dissipation of

8 herbicides and the soil microbial structure were assessed under different agricultural

9 practices, such as the repeated application of herbicides (twice), in unamended and

10 amended soils with two organic amendments derived from green compost (GC1 and

11 GC2) and with non-irrigation and irrigation regimes. The results obtained indicate

12 slower dissipation for triasulfuron than for prosulfocarb. The $50 \%$ dissipation time

$13\left(\mathrm{DT}_{50}\right)$ decreased under all conditions for the second application of triasulfuron,

14 although not for prosulfocarb. The $\mathrm{DT}_{50}$ values for both herbicides increased in the GC2

15 amended soil with the highest organic carbon (OC) content. The $\mathrm{DT}_{50}$ values decreased

16 for prosulfocarb with irrigation, but not for triasulfuron, despite its higher water

17 solubility. The herbicides did not have any significant effects on the relative population

18 of Gram-negative and Gram-positive bacteria during the assay, but the relative

19 abundance of Actinobacteria increased in all the soils with herbicides. At the end of the

20 assay (215 days), the negative effects of herbicides on fungi abundance were significant

21 ( $p<0.05)$ for all the treatments. These microbiological changes were detected in non-

22 irrigated and irrigated soils, and were more noticeable after the second application of

23 herbicides. Actinobacteria could be responsible for the modification of herbicide

24 degradation rates, which tend to be faster after the second application. This study makes

25 a useful contribution to the evaluation of the soil environment and microbiological risks 
due to the long-term repeated application of herbicides under different agricultural management practices.

Keywords: Herbicide, microbial diversity, dissipation, amended soil, repeated application, irrigation.

\section{Introduction}

The structure of soil microbial communities and the changes produced in them by different environmental impacts is of great interest nowadays (Barra Caracciolo et al.

2015). Microbial activity is an accurate indicator of soil quality because soil

microorganisms play a key role in organic matter $(\mathrm{OM})$ decomposition and in the biogeochemical cycles that affect soil fertility (Pascual et al. 2000; García-Orenes et al. 2013). This microbial activity could be affected by the presence of pesticide residues in soil that pose a potential risk to soil ecology (Cycoń et al. 2013; Fang et al. 2018). Modern intensive farming involves the application of large quantities of pesticides during the crop growth period (Nyamwasa et al. 2018). In fact, the residues of herbicides, insecticides and fungicides have been detected in soils in agricultural areas across different countries in a broad range of concentrations (Li et al. 2014; Pose-Juan et al. 2015) which could modify soil microbial biodiversity. Residues of these agrochemicals depend on their dissipation in soils, being modified by different environmental factors (soil type, soil OM, weather, temperature, irrigation), pesticide

46 formulation (individual or combined compounds), and application method (single or repeated application) (Arias-Estévez et al. 2008). This widespread use of pesticides could therefore lead to a potential decrease in soil microbial biodiversity, with a negative impact on crop yields (Baxter and Cummings 2008), which could be increased by the widespread loss of soil OM detected in recent years (Pascual et al. 2000). 
A common practice used in agriculture to increase soil OM content involves the application of organic residues as soil amendments, with the aim being to improve soil fertility and stability, as well as stimulate microbial growth (Bastida et al. 2015).

Organic residues of different origins (urban, agricultural or industrial) are generated in large quantities, and the improvement in soil properties due to their OM content has been well documented (Aranda et al. 2015; Bastida et al. 2015). However the combined application of pesticides and organic residues modifies the physicochemical behaviour of pesticides applied to soils, mainly through their adsorption-desorption (Marín-Benito et al. 2013, 2014). Changes in mobility or the formation of bound residues could occur depending on OM composition, which has implications regarding their bioavailability and total dissipation and consequences for overall soil microbial 62 activity.

Studies on pesticide dissipation and its effects on soil microorganisms have been reported in unamended and amended soils. In general, these studies focus on the effect of a single compound with single application (Cycoń et al. 2013; Álvarez-Martín et al. 2016; Pose-Juan et al. 2017; Singh et al., 2018). They have been carried out in laboratory conditions, while few results have been reported from field experiments with more realistic environmental conditions (Herrero-Hernández et al. 2015). However, studies on the effects that combined application of pesticides have on their dissipation

70 (Vischetti et al. 2008; Fang et al. 2018) and/or the effects of the repeated application of 71 pesticides on soil microbial communities are scarcer in the literature (Baxter and 72 Cummings 2008; Tortella et al. 2013; Fang et al. 2015; Wang et al. 2015). Soil microbial abundance and structure were evaluated through different approaches, and the part soil microorganisms play in the enhanced dissipation of pesticides after repeated applications has been reported. Nevertheless, these investigations have been scarcely 
assessed under field conditions using combined commercial formulations of pesticides, and most of these studies have been carried out in unamended soils (Kaur and Bhullar 2017; Kaur et al. 2017).

Triasulfuron (2-(2-chloroethoxy)-N-[[(4-methoxy-6-methyl-1,3,5-triazin-2-yl) amino] carbonyl] benzene sulfonamide) is a mobile herbicide in soil due to its high water solubility and low hydrophobicity (EFSA 2015), while prosulfocarb (S(phenylmethyl) dipropylcarbamothioate) is a hydrophobic herbicide with high adsorption, low mobility and a moderate persistence in soil (EFSA 2007a). These herbicides of the sulfonylurea and thiocarbamate group, respectively, are used on preand post-emergence in winter cereals (wheat, barley) and other crops (PPDB 2018). No study has been made of the combined long-term effect that triasulfuron and prosulfocarb have on their dissipation rates and soil microbial biomass and structure, although they are repeatedly applied to a broad range of crops. Compounds of the chemical groups sulfonamide and thiocarbamate, such as triasulfuron and prosulfocarb, are usually recommended in cereals for individual or joint use for controlling weeds in rainfed and

91 irrigated cereal crops (Cirujeda and Taberner 2010; Bajya et al. 2015). Relevant changes in soil microbial abundance, activity and structure have already been reported by the authors in a previous paper (García-Delgado et al. 2018) when triasulfuron and prosulfocarb were applied as a combined formulation in unamended and amended soils with green compost (GC) under field conditions. GC is

96 the biodegradable organic residue from pruning in urban gardens and parks with an OM 97 content higher than $15 \%$ (BOE 2013). The results were obtained for a single application of herbicides after the short-term dissipation of herbicides. Little is known about the 
100 the soil microbial structure under field conditions. Repeated herbicide application,

101 different soil OC content from organic amendments, and/or irrigation may modify

102 herbicide dissipation. The study of these factors would increase our knowledge on the

103 effect herbicides have on soil microbial communities.

104 The aim here was therefore to assess the changes in soil microbial communities

105 during the dissipation of two herbicides continuously applied under different

106 agronomical practices. A combined commercial formulation of triasulfuron and

107 prosulfocarb (Aurus Plus ${ }^{\circledR}$ ) was applied twice to an unamended soil and one amended

108 with two organic amendments derived from green compost (GC1 and GC2) and with

109 non-irrigation and irrigation regimes. The effect of these factors on the dissipation of

110 herbicides $\left(\mathrm{DT}_{50}\right)$ and on the soil microbial structure was studied under field conditions.

111 The study makes a useful contribution to the evaluation of environmental and

112 microbiological risks due to the combined long-term application of herbicides under

113 different management practices in agriculture.

115 2. Materials and methods

116 2.1. Herbicides

117 The commercial formulation of triasulfuron (TSF) (2-(2-chloroethoxy)-N-[[(4-

118 methoxy-6-methyl-1,3,5-triazin-2-yl) amino] carbonyl] benzene sulfonamide) (20\% p/p)

119 and prosulfocarb (PSC) (S-(phenylmethyl) dipropylcarbamothioate) (80\% p/v) (Auros

120 Plus $^{\circledR}$, Syngenta Agro S.A., Madrid, Spain) was used in the field study. Analytical

121 standards of both herbicides (purity > 98.9\%) were supplied by Sigma Aldrich Química

122 S.A. (Madrid, Spain). Water solubility is 815 and $13.0 \mathrm{mg} \mathrm{L}^{-1}$ and $\log \mathrm{K}_{\mathrm{ow}}$ is -0.59 and

1234.48 for triasulfuron and prosulfocarb, respectively (PPDB 2018).

124 


\subsection{Organic residues}

126 Two green composts formed by composted vegetal residues were used. They

127 were supplied by the local authority (GC1) and by the nursery "El Arca" (GC2) from

128 Salamanca (Spain). Their main physicochemical characteristics on a dry weight basis

129 were determined by standard methods (Sparks et al., 1996) and are as follows: pH 7.33

130 and 7.58, organic carbon (OC) content $9.80 \%$ and $24.1 \%$, dissolved organic carbon

131 (DOC) content $0.353 \%$ and $0.700 \%$, total $\mathrm{N} 1.04 \%$ and $1.10 \%, \mathrm{C} / \mathrm{N}$ ratio 9.42 and 21.9 ,

132 and ash percentage $74.5 \%$ and $53.0 \%$ for GC1 and GC2, respectively.

\section{2.3. Experimental set-up}

135 A field experiment was conducted in an agricultural soil (sandy clay loam soil,

136 Typic Haploxerept) in the Muñovela experimental farm belonging to IRNASA-CSIC

137 (Salamanca, Spain). An experimental layout of randomized complete blocks was

138 designed in February 2016, with six treatments and three replicates per treatment (18

139 plots of $9 \mathrm{~m}^{2}$ ) corresponding to unamended soil (6 plots, S) and soil amended with GC1

140 (6 plots, S+GC1) or GC2 (6 plots, S+GC2) at the rate of 120 and $180 \mathrm{t} \mathrm{ha}^{-1}$ on a dry

141 weight basis, respectively. For each soil treatment, three plots received only natural

142 rainfall, while other three plots received weekly $2.8 \mathrm{~mm}$ (I). In March 2016, the

143 commercial formulation of triasulfuron and prosulfocarb (Auros Plus ${ }^{\circledR}$ ) was applied to

14418 experimental plots at doses of $250 \mathrm{~g}$ a.i. $\mathrm{ha}^{-1}$ and $11.25 \mathrm{~kg}$ a.i. $\mathrm{ha}^{-1}$, respectively,

145 corresponding to 2.5 times the maximum agronomic dose for both herbicides

146 recommended for heavy soils with a greater adsorption capacity. The increase in the

147 soil's capacity for adsorbing the herbicides after an organic amendment supports the use

148 of doses higher than those recommended to maintain the efficacy of the compounds.

149 Once the herbicide half-lives $\left(\mathrm{DT}_{50}\right)$ were achieved in all plots (after 68 days), the 
150 herbicides were applied again at the same doses in May 2016. A check was made prior

151 to the application of the herbicides to ensure that no amounts of these compounds were

152 detectable in the soil samples. This was as expected, because the plots had no history of

153 triasulfuron and prosulfocarb application in the previous five years. Additionally,

154 eighteen control plots (six by soil treatment) did not receive herbicide application, but

155 nine of them received irrigation.

156 Weather conditions were recorded throughout the experiment (215 days) by a

157 meteorological station located on site (Fig. S1 in Supplementary material). Air

158 temperature ranged from $1.7^{\circ} \mathrm{C}$ to $14.6^{\circ} \mathrm{C}$ (mean air temperature $8.3^{\circ} \mathrm{C}$ ) and from 10.5

$159{ }^{\circ} \mathrm{C}$ to $26.3{ }^{\circ} \mathrm{C}$ (mean air temperature $19.1{ }^{\circ} \mathrm{C}$ ) during the first (0-68 days) and the second

160 (69-215 days) period of the application, respectively. Cumulative precipitation and

161 additional irrigation were $139.2 \mathrm{~mm}$ and $11.2 \mathrm{~mm}$ during the first application, and 46.6

$162 \mathrm{~mm}$ and $58.8 \mathrm{~mm}$ during the second application of herbicides, respectively. Total

163 cumulative precipitation and additional irrigation were $185.8 \mathrm{~mm}$ and $70 \mathrm{~mm}$,

164 respectively.

165

166

2.4. Soil sampling and herbicide extraction and analysis

167 Surface soil samples from 0 to $10 \mathrm{~cm}$ were collected to determine herbicide

168 dissipation at different times between 0 and 68 days (first herbicides' ${ }^{\prime}$ application) and

169 between 69 and 215 days (second herbicides' application) and to determine soil

170 microbial structure at $0,28,69,97,124$ and 215 days. Soil samples were collected,

171 processed and characterized following the methods described by Marín-Benito et al.

172 (2018a) and García-Delgado et al. (2018) (complete information is included in

173 Supplementary material). Soil characteristics are included in Table 1. Soil samples were

174 sieved $(<2 \mathrm{~mm})$ and moisture content of the bulk sample was determined. Duplicate 
175 subsamples of moist soil $(6 \mathrm{~g})$ were extracted with methanol $(12 \mathrm{~mL})$ by shaking and

176 sonication. The determination of the herbicides in the soil extracts was performed by

177 HPLC-MS (Waters Assoc., Milford, MA, USA). The molecular ions [m/z] 402.8

178 (triasulfuron) and 252.4 (prosulfocarb) were monitored and the retention times were 6.1

$179 \min$ and $14.1 \mathrm{~min}$, respectively. A detailed description of the herbicide extraction and

180 analytical methods is included in Supplementary material.

181

\subsection{Soil microbial community by PLFA analysis}

The soil microbial community composition of the soil samples was determined

184 using phospholipid fatty acid (PLFA) analysis, as described in Frostegård et al. (1993).

185 Lyophilized soils samples were extracted with a one-phase chloroform-methanol-

186 phosphate buffer solvent by sonication. Extracts were purified by SPE and polar lipids

187 were transesterified with methanol-KOH. Finally, hexane extracts containing the

188 resultant fatty acid methyl esters were analyzed by gas chromatography. Quantification

189 was performed using an Agilent 7890 gas chromatograph (Agilent Technologies,

190 Wilmington, DE, USA) equipped with a 25-m Ultra 2 (5\% phenyl)-methylpolysiloxane

191 column (J\&W Scientific, Folsom, CA, USA) and a flame ionization detector. PLFAs

192 were identified using bacterial fatty acid standards and software from the Microbial

193 Identification System (Microbial ID, Inc., Newark, DE, USA). Specific PLFAs (Zelles,

194 1999) were used as biomarkers to quantify the relative abundances of Gram negative

195 (monounsaturated fatty acids and cyclopropyl 17:0 and 19:0) and Gram positive (iso

196 and anteiso saturated branched fatty acids) bacteria, Actinobacteria (10-methyl fatty

197 acids) and fungi (18:2 $\omega 6$ cis).

198

199

\subsection{Data analysis}


The dissipation kinetics for triasulfuron and prosulfocarb were fitted to a single

201 first-order (SFO) or first-order multicompartment (FOMC) models and values for the time to $50 \%$ dissipation $\left(\mathrm{DT}_{50}\right)$ were estimated using the Excel Solver add-in package (FOCUS, 2006). More details about the fitting of the dissipation kinetics are included in

Supplementary material.

Analysis of variance (ANOVA) was used to evaluate the effects of the different treatments (green compost application, repeated herbicide application and irrigation) on herbicide dissipation. Standard deviation (SD) was used to indicate variability among replicates. Fisher's least significant difference (LSD) method, at a confidence level of 95\%, was determined with IBM SPSS Statistics v24 software package (SPSS Inc.

210 Chicago, USA). previous Levene variance homogeneity test to determine significant differences between treatments at each sampling time. Means were compared by either Tukey or Games-

214 Howell post hoc test based on whether or not variance homogeneity was met,

215 respectively $(p<0.05)$. Pearson correlation coefficients between the remaining

216 concentration and percentages of herbicides, and microbial biomass and structure were

217 determined to elucidate how variables are related to each other. ANOVA and

218 correlation analyses were carried out using the IBM SPSS Statistics v24 software

219 package (SPSS Inc. Chicago, USA). Principal component analysis (PCA) was

220 performed, with PAST v3.15 software (Hammer et al. 2001), to determine the most

221 meaningful variables and the global impact of the herbicides and soil treatments on soil microbial community. In addition to PCA, PERMANOVA analysis was performed to determine the significance of herbicides application, sampling time, soil treatments and

224 their interactions. 


\section{Results and discussion}

3.1. Herbicide dissipation after repeated application in soils, soil amendment, and irrigation conditions

The dissipation kinetics of herbicides after the first and second application fit the

230 SFO model for most of the treatments, and only in four plots the dissipation kinetics

231 provide a better fit for the FOMC model (Figs. S2 and S3 in Supplementary material).

232 Other authors also report that the SFO equation is the model that best fits triasulfuron and prosulfocarb dissipation in the field (Rouchaud et al. 1997; Sarmah et al. 2000). The $\mathrm{DT}_{50}$ values were used to compare the dissipation rates of triasulfuron and prosulfocarb under the different conditions studied (herbicide type, repeated dose, soil amendment, and irrigation) (Tables 2 and 3). The dissipation curves show a continuous decrease in triasulfuron and prosulfocarb concentrations over time. It is faster for prosulfocarb than for triasulfuron for all the treatments studied, as indicated by the lower $\mathrm{DT}_{50}$ values. The faster dissipation of prosulfocarb could be due to processes of adsorption,

240 biodegradation, mineralization, and/or volatilization, as reported previously (Marín-

241 Benito et al., 2018b; Braun et al., 2017; EFSA, 2007a). with those determined in a previous work, when they were applied as a single or

244 combined formulation in unamended or GC-amended soils, albeit in a lower dose than

245 in this study (Marín-Benito et al., 2018a). The repeated application of triasulfuron has

246 an effect on its persistence, with higher dissipation rates, and DT 50 values 1.3 to 3 times

247 lower than after the first application (Table 2). These results indicate that the persistence

248 of triasulfuron was lower after the second application. This is consistent with the

249 remaining percentages of triasulfuron at 68 days after the first application, ranging 
between 14\% - 51\%, and at 69 days after the second application (corresponding to 138 days after the first application), being between $3 \%-17 \%$ in the soils with the different treatments. Other authors have also reported accelerated dissipation after repeated pesticide applications due to the faster metabolism caused by enhanced biodegradation, which could lead to a reduction in pesticide efficacy in some cases (Baxter and Cummings 2008; Fang et al. 2018).

The $\mathrm{DT}_{50}$ values for prosulfocarb decreased by up to 1.3 and 1.6 times after its second application in irrigated $\mathrm{S}$ and $\mathrm{S}+\mathrm{GC} 2$ soils, respectively, but the $\mathrm{DT}_{50}$ values were, in general, similar for all the other soil treatments (Table 3). However, the remaining percentages of prosulfocarb at 68 days after the first application were lower

$260(0 \%-3 \%)$ than those at 69 days after the second application (corresponding to 138 days after the first application) (2\%-21\%). These results indicate that the amounts of prosulfocarb remaining after the second application decreased more slowly over time than after the first application, without fully dissipating. Rouchaud et al. (1997) have reported that repeated prosulfocarb application to a barley crop enhanced soil biodegradation. However, the decrease in prosulfocarb concentrations after the second application and over the course of 50\% dissipation was slower than after the first application, and this resulted in a higher persistence of the herbicides in the soil at the end of the assay (215 days) (Fig. S3).

The $\mathrm{DT}_{50}$ values for the dissipation of triasulfuron and prosulfocarb after the two 270 applications were higher in $\mathrm{S}+\mathrm{GC} 2$ than in $\mathrm{S}$ or $\mathrm{S}+\mathrm{GC} 1$. The $\mathrm{DT}_{50}$ values increased by

$2713.1-1.8$ times and by 2.0-1.9 times compared to the unamended soil. These results are 272 related to the higher OC content in S+GC2 than in S+GC1, which could help increase 273 the persistence of these herbicides in the top soil, decreasing its leaching (Marín-Benito 274 et al., 2018b). In fact, a significant and positive correlation $\left(\mathrm{R}^{2}=0.828, \mathrm{p}<0.001\right)$ was 
275 found between the $\mathrm{DT}_{50}$ values of triasulfuron and prosulfocarb and OC content.

276 Furthermore, the adsorption of both herbicides by S+GC2 could occur with the possible

277 formation of bound residues and a potential decrease in bioavailability and

278 biodegradation (Gennari et al. 2002; Said-Pullicino et al. 2004). The relationship

279 between the adsorption and degradation of these herbicides has also been reported in

280 previous works (Nègre et al., 2006; Said-Pullicino et al., 2004). A significant and

281 positive correlation was also found here between the $\mathrm{K}_{\mathrm{d}}$ determined for triasulfuron ( $\mathrm{S}$, $0.31 \pm 0.01 \mathrm{~mL} \mathrm{~g}^{-1} ; \mathrm{S}+\mathrm{GC} 1,0.38 \pm 0.09 \mathrm{~mL} \mathrm{~g}^{-1}$ and $\mathrm{S}+\mathrm{GC} 2,0.67 \pm 0.03 \mathrm{~mL} \mathrm{~g}^{-1}$ ) or for prosulfocarb $\left(\mathrm{S}, 21.6 \pm 5.55 \mathrm{~mL} \mathrm{~g}^{-1} ; \mathrm{S}+\mathrm{GC} 1,24.7 \pm 7.62 \mathrm{~mL} \mathrm{~g}^{-1}\right.$ and $\mathrm{S}+\mathrm{GC} 2,57.1 \pm$ $2.09 \mathrm{~mL} \mathrm{~g}^{-1}$ ) (Marín-Benito et al., 2018b) and the $\mathrm{DT}_{50}$ values determined for the first and second dissipation kinetics $\left(\mathrm{R}^{2}=0.665, \mathrm{p}<0.02\right.$, triasulfuron $)$ and $\left(\mathrm{R}^{2}=0.860\right.$, $\mathrm{p}<0.001$, prosulfocarb).

Additional irrigation did not significantly modify the dissipation rates of triasulfuron after the two applications in S-I or S+GC1-I, but it decreased in S+GC2-I after the first application. Similarly, Sarmah et al. (2000) have reported that the $\mathrm{DT}_{50}$ values of triasulfuron in an unamended soil under field conditions remained unchanged when the soil received $89 \mathrm{~mm}$ of irrigation compared to the non-irrigated soil. The $\mathrm{DT}_{50}$ values of prosulfocarb were similar in irrigated soils after the first herbicide application. However, the dissipation rates increased in S-I and to a greater extent in S+GC2-I after the second herbicide application. Irrigation could lead to a higher potential degradation and/or leaching of herbicides through the soil profile. dissipation of triasulfuron and prosulfocarb revealed the possible effect of temperature for explaining the accelerated degradation of triasulfuron after the second application. 
$300{ }^{\circ} \mathrm{C}$ after the second herbicide application. This result is consistent with the increase in

301 the degradation rate of 2.58 times when the temperature increases by $10{ }^{\circ} \mathrm{C}$, as

302 determined by the European Food Safety Authority (EFSA 2007b). Dinelli et al. (1998)

303 have reported that temperature had an effect on the degradation rate of triasulfuron, and

304 the $\mathrm{DT}_{50}$ value decreased three times when temperature increased from $10{ }^{\circ} \mathrm{C}$ to $20{ }^{\circ} \mathrm{C}$.

305 Stork (1995) has observed that triasulfuron degradation rates increased with soil

306 temperature, but they were not affected by soil water content. Temperature had no effect

307 for prosulfocarb after the second application of herbicide because faster dissipation

308 occurred only in irrigated treatments of S-I and S+GC2-I and could be explained by

309 other processes, as previously indicated.

310

311 3.2. Effect of herbicides residues, organic amendments and irrigation regimes on the soil microbial structure

313 The total microbial population behaved in a similar way towards herbicides in

314 both irrigated and non-irrigated soils. The amounts of herbicide residues, in total $\left(\mu \mathrm{g} \mathrm{g}^{-}\right.$

$315^{1}$ ) or relative concentration $(\%)$, were positively related to the total microbial population

$316\left(\mathrm{nmol} \mathrm{g}^{-1}\right)$ (Tables 4 and 5). It means a decrease in this population while the dissipation

317 of herbicides occurs. The toxicity of pesticides towards soil microorganisms is well

318 described in the literature, mainly in high doses (El Azhari et al., 2018; Fang et al.,

319 2018; Franco-Andreu et al., 2016a; Kalia and Gosal, 2011; Wang et al., 2015).

320 However, previous studies do not provide consistent results on the toxicity of

321 triasulfuron in soil microbiology between laboratory and field scale. Lupwayi et al.

322 (2004) and Pose-Juan et al. (2017) report that triasulfuron has no toxic effects on

323 microbial biomass at field and laboratory scale, respectively. In contrast, Sofo et al.

324 (2012) have reported toxic effects at laboratory scale for an agronomic dose or higher. 
325 A recent study at field scale using a lower dose of triasulfuron than in this work agreed

326 with the latter, indicating a decrease in microbial biomass due to the toxic effects of

327 triasulfuron, and more so a combination of triasulfuron and prosulfocarb in the

328 unamended and GC amended soils (García-Delgado et al., 2018). Therefore, there is

329 evidence of the toxicity of triasulfuron and prosulfocarb towards soil microbiota.

330 Additionally, our results indicated that the bacteria/fungi ratio was negatively correlated

331 with the herbicide residues, i.e. the soils had more bacteria and a lower population of

332 fungi with respect to the initial situation. This effect has also been observed in soils

333 fumigated with imazethapyr, herbicide with the same mechanisms of action than

334 triasulfuron (Zhang et al., 2010).

335 The presence of triasulfuron and prosulfocarb reveal different effects on

336 microbial structure in both irrigated and non-irrigated soils during the field assay. The

337 most abundant microorganisms in the irrigated and non-irrigated soils were Gram-

338 negative bacteria followed by Gram-positive bacteria, Actinobacteria, and finally fungi

339 (Figs. 1 and 2). A different composition of the microbial structure could be expected

340 due to the different irrigation regime and organic amendment management, as reported

341 by Franco-Andreu et al. (2016a, 2016b) and Sun et al. (2017). These authors reported

342 that non-irrigated soils have been related to a higher proportion of Gram-positive

343 bacteria than in irrigated soils because of the higher rigidity of cell walls compared to

344 Gram-negative bacteria. However, the application of organic amendments may reduce

345 this phenomenon (Franco-Andreu et al., 2016b) because of the higher water retention by

346 the OM from organic amendments. In this study, the dominance of Gram-negative

347 bacteria irrespective of irrigation could also be explained by the fact the drought

348 conditions of non-irrigated soils were not extreme, as was the case in the above

349 references. The cumulative rainfall during the assay was $185.8 \mathrm{~mm}$ and irrigation was 
$70 \mathrm{~mm}$ (Fig. S1 in Supplementary material), so the irrigated soils received a total of

$351255.8 \mathrm{~mm}$ of water, $38 \%$ more than the non-irrigated soils. significant effects on the relative populations of Gram-negative and Gram-positive

354 bacteria during the assay (Fig. 1). However, herbicides tended to increase the relative

355 abundance of Actinobacteria after the second application (69 - 215 days) in S-H,

356 S+GC1-H and S+GC2-H (Fig. 1). Baxter and Cummings (2008) have described the

357 changes in soil microbial structure after three consecutive applications of the herbicide

358 bromoxynil and, what's more, at high doses. The change in bacteria structure prompted

359 a significant decrease in the Gram-negative/total Gram-positive (sum of Gram-positive

360 group and Actinobacteria) bacteria ratio between treatments with and without herbicides

361 in $\mathrm{S}+\mathrm{GC} 1$ and $\mathrm{S}+\mathrm{GC} 2$ at the end of the assay (Fig. S4 in Supplementary material).

362 Similar results were found in soils fumigated with imazethapyr (Zhang et al., 2010). Results indicated that the residual concentrations of herbicides were positively

364 correlated with the relative percentage of Gram-positive bacteria and fungi, and

365 negatively correlated with Actinobacteria (Table 4). Therefore, the dissipation of

366 herbicides negatively affected Gram-positive bacteria and fungi, whereas it enhanced

367 the relative population of Actinobacteria. So, fungi behaved in the opposite way to

368 Actinobacteria. After the first application of herbicides (28 days), the relative

369 population of fungi in S-H and S+GC1-H was significantly lower than in S and S+GC1, 370 although $\mathrm{S}+\mathrm{GC} 2$ and $\mathrm{S}+\mathrm{GC} 2-\mathrm{H}$ did not record significant differences (Fig. 1). At the

371 end of the assay (215 days), the negative effects of herbicides on fungi abundance were 372 significant $(p<0.05)$ for all the treatments, and produced a generalized increase in the 373 bacteria/fungi ratio (Fig. S4 in Supplementary material). This suggests that fungi were 374 sensitive to the herbicides triasulfuron and prosulfocarb. The opposite effect between 
375 fungi and bacteria (Santás-Miguel et al., 2018) was because of the significant increase

376 in Actinobacteria, the minimal effects of herbicides on Gram-negative and Gram-

377 positive bacteria, and the significant decrease in fungi (Fig. 1).

The irrigation of soils enhanced the effects of herbicides in unamended and

379 amended soils. The relative abundance of Gram-negative bacteria between the first and

380 second herbicide applications (28 days) was lower in S+GC2-I-H than in S+GC2-I, but

381 there were no significant differences between S-I and S-I-H or between S+GC1-I and

382 S+GC1-I-H (Fig. 2). The same behaviour was found after the second herbicide

383 application at 69 and 97 days. At the end of the assay (215 days), nonetheless, the

384 decrease in Gram-negative abundance was significant $(p<0.05)$ for all the soil

385 treatments with herbicides (S-I-H, S+GC1-I-H and S+GC2-I-H). The effect on Gram-

386 positive bacteria was only significant $(p<0.05)$ at the end of the assay in S+GC2-I,

387 where the presence of herbicides increased the relative population of Gram-positive

388 bacteria.

The relative percentage of Gram-negative bacteria was negatively correlated

390 with the prosulfocarb residue (Table 5). In contrast, the relative percentage of Gram-

391 positive bacteria was positively correlated with the prosulfocarb residue. Therefore, the

392 presence of prosulfocarb could induce the substitution of Gram-positive bacteria by

393 Gram-negative bacteria. The same phenomenon could be found between Actinobacteria

394 (negatively correlated with the herbicide residues) and fungi (positively correlated with

395 the herbicide residues). The relative population of Actinobacteria was significantly

396 higher with herbicides in all the soil treatments (S-I-H, S+GC1-I-H and S+GC2-I-H) as

397 happened in non-irrigated soils. Despite the significant differences found during the

398 assay for all the treatments, the ratio Gram-negative/total Gram-positive bacteria (Fig.

399 S5 in Supplementary material) only recorded significant differences between S+GC2-I 
and $\mathrm{S}+\mathrm{GC} 2-\mathrm{I}-\mathrm{H}$. In this soil, as in non-irrigated soils, the application of herbicides

401 decreased this ratio accordingly with the increased persistence of herbicides (higher $\left.402 \mathrm{DT}_{50}\right)$.

In contrast to Actinobacteria, the effects of herbicides on fungi followed the opposite trend by decreasing their relative abundance over time in all soil treatments.

405 Moreover, the fungal decrease was clearly reflected in the bacteria/fungi ratio (Fig. S5

406 in Supplementary material). The increase in this ratio at the end of the assay again 407 reflected the bacteria - fungi antagonism. The negative effects of some herbicides on 408 fungi have been previously reported (Martin-Laurent et al., 2003; Wu et al., 2014).

409 However, other studies have shown the negative effects that some herbicides, including 410 triasulfuron and prosulfocarb, have on fungi at the beginning of the incubation period, 411 although the fungal population subsequently recovered (Cycoń et al., 2013; García412 Delgado et al., 2018; Wang et al., 2015; Zhang et al., 2010). In this study, the 413 significant decline $(p<0.05)$ in the relative abundance of fungi could be related to the 414 consecutive applications of high doses of a mixture of two herbicides. In addition, 415 between 0 and 69 days the GC-amended soils (S+GC1 and S+GC2) tended to decrease 416 the relative abundance of fungi with respect to $\mathrm{S}$, as previously described by García417 Delgado et al. (2018) and Pose-Juan et al. (2017).

418 The microbiological changes in soils after the second application of herbicides 419 could be responsible for the change in their degradation rates, which tend to be faster 420 after the second application when the relative population of Actinobacteria is enhanced. 421 These organisms are known to be good degraders of complex substrates (Pose-Juan et al., 2017). 
426 PCA including the results in non-irrigated (Fig. 3 A, B and C) and irrigated (Fig. 3 D, E and F) soils. A PERMANOVA analysis (Table S1 in Supplementary material) testing for the significance of the effects on the relative abundances of PLFAs of herbicide application, sampling time, soil treatments and their respective interactions revealed the statistical significance of the three factors in non-irrigated and irrigated soils. With respect to non-irrigated soils, unamended and amended soils recorded different PCA profiles. The soil treatment was not significant, but the application of herbicides was statistically significant in all three soil treatments $(\mathrm{S}, \mathrm{S}+\mathrm{GC} 1$ and S+GC2) (Table S1). The application of herbicides in soil without compost (S-H) clearly enhanced the abundance of Actinobacteria and reduced the relative abundance of fungi and Gram-negative bacteria. S+GC1-H and S+GC2-H were related to a low relative abundance of fungi and a high relative abundance of Actinobacteria and Gram-negative bacteria. In contrast, amended soils without herbicides were related to a high relative abundance of fungi and Gram-positive bacteria. In non-irrigated soils, therefore,

440 herbicides had a clearly negative effect on fungi and Gram-positive bacteria, while 441 promoting the relative abundance of Actinobacteria, irrespective of compost use. S-H was related to high relative abundance of Gram-negative bacteria, mainly at $124-215$ days, while S+GC1-H and S+GC2-H recorded a closer relationship with Gram-negative

444 bacteria than S+GC1 and S+GC2 (Fig. 3 A, B and C). In a laboratory assay, soil

445 fumigated with another sulfonylurea herbicide, azimsulfuron, enhanced microbial 446 diversity by detecting different Gram-negative bacteria that were not found in a non447 fumigated soil (Valle et al., 2006). S+GC1-H and S+GC2-H produced slower 448 triasulfuron degradation than $\mathrm{S}-\mathrm{H}$, so the microbial shift may be deeper in the former. 
The microbiology of non-irrigated soils was exposed to three clear stress factors, namely, high doses of triasulfuron and prosulfocarb, two consecutive applications, and drought conditions. In this respect, the toxic effects of pesticides can be enhanced, with negative effects on microbial composition, enzyme activity and pesticide degradation (Franco-Andreu et al., 2016a). This could be the cause of the significant impact triasulfuron and prosulfocarb have on the microbial structure of unamended and GCamended soils, as reported here. In contrast, a previous study under similar conditions but with lower herbicide doses revealed an impact on the microbial structure of unamended soil but not on the microbial structure of GC-amended soil (García-Delgado et al., 2018). Therefore, the capacity of organic amendments to buffer the effects of herbicides on the microbial structure could be limited by herbicide doses or consecutive applications.

The three soil treatments in irrigated soils had significant effects (Table S1 in

Supplementary material) on the soil microbial structure. Unamended and GC1 amended soils (with and without herbicides) had a similar distribution in PCA with no significant relationship with any factor (Fig. $3 \mathrm{D}$ and E). In contrast, GC2 amended soils (with and without herbicides) had a strong relationship with Actinobacteria and a weak one with fungi (Fig. 3F). The negative effects of GC or other organic amendments on fungal abundance has previously been reported at both laboratory scale (Pose-Juan et al., 2017) and field scale (García-Delgado et al., 2018). The application of herbicides in irrigated soils had some similarities with non-

470 irrigated soils. The soil microbial structure of irrigated soils after herbicide application 471 shifted towards a higher proportion of Actinobacteria and a lower relative amount of 472 fungi, as was the case in non-irrigated soils. The presence or absence of herbicides and 473 their interaction over time was significant in unamended soil. S-I was related to a high 
proportion of Gram-positive bacteria and fungi. In contrast, S-I-H evolved from points

475 related to fungi towards a clear relationship with Actinobacteria and Gram-negative

476 bacteria at the end of the assay. The herbicide factor was not significant in S+GC1

477 treatment. However, the time factor and the herbicide* sampling time interaction were

478 significant. In fact, the evolution of S+GC1-I-H (dark blue symbols in Fig. 3) tends to

479 be more closely related to Actinobacteria and less so to fungi over time. In contrast, the

480 changes in microbial structure over time in $\mathrm{S}+\mathrm{GC} 1$ seem to be related to the variation in

481 the proportion of Gram-negative and Gram-positive bacteria because of the dispersion

482 of points in component 1 and the low values of points in component 2, being closely

483 related to fungi and Actinobacteria. The application of herbicides in GC2-amended soils

484 and their interaction with sampling time were significant. PCA showed a clear

485 differentiation between S+GC2-I and S+GC2-I-H. S+GC2-I was related to a high

486 relative abundance of Gram-positive bacteria, mainly at 215 days. In contrast, S+GC2-I-

$487 \mathrm{H}$ was related to a high relative abundance of Actinobacteria and Gram-negative

488 bacteria. In addition, there was a clearly negative relationship with the abundance of

489 fungi in both, S+GC2-I and S+GC2-I-H treatments, as described above.

490 After herbicide application, all the soils, irrespective of irrigation conditions,

491 tended to enhance the relative population of Actinobacteria, mainly after the second

492 application of herbicides, when their $\mathrm{DT}_{50}$ values were lower than the first one. The

493 remaining triasulfuron concentration 69 days after the second application recorded

494 lower concentrations than in the first application. Dissipation therefore increased in the

495 second application, when Actinobacteria increased their relative abundance. In contrast,

496 the remaining concentrations of prosulfocarb were higher after the second application. It

497 therefore seems clear that a high relative abundance of Actinobacteria plays a key role 
498 in herbicide dissipation, being positive in the case of triasulfuron and negative in the

499 case of prosulfocarb degradation.

500

501

\section{Conclusions}

502 The dissipation of triasulfuron and prosulfocarb in an agricultural soil under field

503 conditions is influenced by the type and amount of green compost applied to the soil

504 and by the irrigation regime. Two consecutive applications of triasulfuron increase the 505 dissipation rate of this herbicide, although in the case of prosulfocarb it produces an

506 accumulation of residual herbicide after the second application. A positive correlation

507 between the amounts of herbicide residues and the total microbial population led to a

508 decrease in the microbial population during the dissipation of herbicides and to a certain

509 toxicity of herbicides for the microbial community. The microbial structure of

510 unamended and GC-amended soils is modified after two consecutive applications of the

511 herbicides triasulfuron and prosulfocarb. Herbicides increase the relative population of

512 Actinobacteria and reduce the relative population of fungi compared to the initial

513 situation in all the conditions studied. Actinobacteria seems to be responsible for the

514 increase in the of degradation rate of triasulfuron after the second application.

515

\section{Acknowledgements}

517 This work was funded by Junta de Castilla y León (project CSI240U14). V.B.V.,

518 C.G.D. and J.M.M.B. thank Junta de Castilla y León and MINECO by their predoctoral,

519 Juan de la Cierva-Formación (JCFI-2015-23543) and Juan de la Cierva-Incorporación

520 (IJCI-2014-19538) contracts, respectively.

521

\section{References}


523 Álvarez-Martín, A., Hilton, S.L., Bending, G.D., Rodríguez-Cruz, M.S., Sánchez-

524 Martín, M.J., 2016. Changes in activity and structure of the soil microbial

525 community after application of azoxystrobin or pirimicarb and an organic

526 amendment to an agricultural soil. Appl. Soil Ecol. 106, 47-57.

527 doi:10.1016/j.apsoil.2016.05.005

528 Aranda, V., Macci, C., Peruzzi, E., Masciandaro, G., 2015. Biochemical activity and

529 chemical-structural properties of soil organic matter after 17 years of amendments

530 with olive-mill pomace co-compost. J. Environ. Manage. 147, 278-285.

531 doi:10.1016/j.jenvman.2014.08.024

532 Arias-Estévez, M., López-Periago, E., Martínez-Carballo, E., Simal-Gándara, J.,

533 Mejuto, J.C., García-Río, L., 2008. The mobility and degradation of pesticides in

534 soils and the pollution of groundwater resources. Agric. Ecosyst. Environ. 123,

$535 \quad$ 247-260. doi:10.1016/j.agee.2007.07.011

536 Bajya, D.R., Parween, T., Lakharan, M.C., Razaaza, S.K., 2015. Efficacy of new

537 formulations of triasulfuron on weeds in wheat (Triticum aestivum) and their

538 residual effects on succeeding maize (Zea mays). Indian J. Agron. 60, 57-60.

539 Barra Caracciolo, A., Bustamante, M.A., Nogues, I., Di Lenola, M., Luprano, M.L.,

540 Grenni, P., 2015. Changes in microbial community structure and functioning of a

541 semiarid soil due to the use of anaerobic digestate derived composts and rosemary

542 plants. Geoderma 245-246, 89-97. doi:10.1016/j.geoderma.2015.01.021 
543 Bastida, F., Selevsek, N., Torres, I.F., Hernández, T., García, C., 2015. Soil restoration

544 with organic amendments: Linking cellular functionality and ecosystem processes.

$545 \quad$ Sci. Rep. 5, 15550. doi:10.1038/srep 15550

546 Baxter, J., Cummings, S.P., 2008. The degradation of the herbicide bromoxynil and its

547 impact on bacterial diversity in a top soil. J. Appl. Microbiol. 104, 1605-1616.

$548 \quad$ doi:10.1111/j.1365-2672.2007.03709.x

549 BOE, 2013. Real Decreto 506/2013, de 28 de junio, sobre productos fertilizantes, BOE.

550 Braun, K.E., Luks, A.K., Schmidt, B., 2017. Fate of the14C-labeled herbicide

551 prosulfocarb in a soil and in a sediment-water system. J. Environ. Sci. Heal. - Part

552 B Pestic. Food Contam. Agric. Wastes 52, 122-130.

553 doi:10.1080/03601234.2016.1248140

554 Cirujeda, A., Taberner, A., 2010. Chemical control of herbicide-resistant Lolium

555 rigidum Gaud. in north-eastern Spain. Pest Manag. Sci. 66, 1380-1388.

556 doi:10.1002/ps.2031

557 Cycoń, M., Wójcik, M., Borymski, S., Piotrowska-Seget, Z., 2013. Short-term effects of

558 the herbicide napropamide on the activity and structure of the soil microbial

559 community assessed by the multi-approach analysis. Appl. Soil Ecol. 66, 8-18.

$560 \quad$ doi:10.1016/j.apsoil.2013.01.014

561 Dinelli, G:, Vicari, A., Accinelli, C., 1998. Degradation and side effects of three

562 sulfonylurea herbicides in soil. J. Environ. Qual. 27, 1459-1464. doi:

$563 \quad 10.2134 /$ jeq1998.00472425002700060023x 
564 EFSA, 2015. Conclusion on the peer review of the pesticide risk assessment of the active substance triasulfuron. EFSA J. 13, 3958. doi:10.2903/j.efsa.2015.3958

566

567

EFSA, 2007a. Conclusion regarding the peer review of the pesticide risk assessment of the active substance clomazone finalised : 27 July 2007. EFSA Sci. Rep. 111, 1-81.

EFSA, 2007b. Opinion on a request from EFSA related to the default Q 10 value used to describe the temperature effect on transformation rates of pesticides in soil. EFSA J. 622, 1-32. doi:10.2903/j.efsa.2008.622

El Azhari, N., Dermou, E., Barnard, R.L., Storck, V., Tourna, M., Beguet, J., Karas, P.A., Lucini, L., Rouard, N., Botteri, L., Ferrari, F., Trevisan, M., Karpouzas, D.G., Martin-Laurent, F., 2018. The dissipation and microbial ecotoxicity of tebuconazole and its transformation products in soil under standard laboratory and simulated winter conditions. Sci. Total Environ. 637-638, 892-906. doi:10.1016/j.scitotenv.2018.05.088

Fang, H., Han, L., Zhang, H., Deng, Y., Ge, Q., Mei, J., Long, Z., Yu, Y., 2018. Repeated treatments of ciprofloxacin and kresoxim-methyl alter their dissipation rates, biological function and increase antibiotic resistance in manured soil. Sci. Total Environ. 628-629, 661-671. doi:10.1016/j.scitotenv.2018.02.116

Fang, H., Lian, J., Wang, H., Cai, L., Yu, Y., 2015. Exploring bacterial community structure and function associated with atrazine biodegradation in repeatedly treated soils. J. Hazard. Mater. 286, 457-465. doi:10.1016/j.jhazmat.2015.01.006

FOCUS, 2006. Guidance document on estimating persistence and degradation kinetics from environmental fate studies on pesticide in EU registration. Report of the 

Sanco/10058/2005 version 2.0.

Franco-Andreu, L., Gómez, I., Parrado, J., García, C., Hernández, T., Tejada, M., 2016a. Behavior of two pesticides in a soil subjected to severe drought. Effects on

Franco-Andreu, L., Gómez, I., Parrado, J., García, C., Hernández, T., Tejada, M., 2016b. Soil biology changes as a consequence of organic amendments subjected to a severe drought. L. Degrad. Dev. 905, 897-905. doi:10.1002/ldr.2663

594 Frostegård, Å., Bååth, E., Tunlid, A., 1993. Shifts in the structure of soil microbial communities in limed forests as revealed by phospholipid fatty acid analysis. Soil

García-Delgado, C., Barba, V., Marín-Benito, J.M., Igual, J.M., Sánchez-Martín, M.J., 598 Biol. Biochem. 25, 723-730.

601 García-Orenes, F., Morugán-Coronado, A., Zornoza, R., Scow, K., 2013. Changes in Rodríguez-Cruz, M.S., 2018. Simultaneous application of two herbicides and green compost in a field experiment: Implications on soil microbial community. Appl. Soil Ecol. 127, 30-40. doi:10.1016/j.apsoil.2018.03.004

605

Gennari, M., Ambrosoli, R., Nègre, M., Minati, J.L., 2002. Bioavailability and 606 biodegradation of prosulfocarb in soil. J. Environ. Sci. Heal. - Part B Pestic. Food Contam. Agric. Wastes 37, 297-305. doi:10.1081/PFC-120004471 
608 Hammer, Ø., Harper, D.A.T., Ryan, P.D., 2001. PAST: Paleontological Statistics

609 software package for education and data analysis. Palaeontol. Electron. 4, 1-9.

$610 \quad$ doi:10.1016/j.bcp.2008.05.025

611 Herrero-Hernández, E., Marín-Benito, J.M., Andrades, M.S., Sánchez-Martín, M.J.,

612 Rodríguez-Cruz, M.S., 2015. Field versus laboratory experiments to evaluate the

613 fate of azoxystrobin in an amended vineyard soil. J. Environ. Manage. 163, 78-86.

614 doi:10.1016/j.jenvman.2015.08.010

615 Kalia, A., Gosal, S.K., 2011. Effect of pesticide application on soil microorganisms.

$616 \quad$ Arch. Agron. Soil Sci. 57, 569-596. doi:10.1080/03650341003787582

617 Kaur, P., Bhullar, M.S., 2017. Effect of repeated application of pendimethalin on its

618 persistence and dissipation kinetics in soil under field and laboratory conditions.

619 Environ. Technol. 1-9. doi:10.1080/09593330.2017.1415378

620 Kaur, P., Randhawa, S.K., Duhan, A., Bhullar, M.S., 2017. Influence of long term

621 application of butachlor on its dissipation and harvest residues in soil and rice. Bull.

622 Environ. Contam. Toxicol. 98, 874-880. doi:10.1007/s00128-017-2070-1

623 Li, Y., Niu, J., Shen, Z., Zhang, C., Wang, Z., He, T., 2014. Spatial and seasonal

624 distribution of organochlorine pesticides in the sediments of the Yangtze Estuary.

625 Chemosphere 114, 233-240. doi:10.1016/j.chemosphere.2014.04.112

626 Lupwayi, N.Z., Harker, K.N., Clayton, G.W., Turkington, T.K., Rice, W.A.,

627 O’Donovan, J.T., 2004. Soil microbial biomass and diversity after herbicide

628 application. Can. J. Plant Sci. 84, 677-685. doi:10.4141/P03-121 
629 Marín-Benito, J.M., Barba, V., Ordax, J.M., Andrades, M.S., Sánchez-Martín, M.J., 630 Rodríguez-Cruz, M.S., 2018a. Application of green compost as amendment in an 631 agricultural soil: Effect on the behaviour of triasulfuron and prosulfocarb under 632 field conditions. J. Environ. Manage. 207, 180-191.

633 doi:10.1016/j.jenvman.2017.11.024

634 Marín-Benito, J.M., Barba, V., Ordax, J.M., Sánchez-Martín, M.J., Rodríguez-Cruz, 635 M.S. 2018b. Recycling organic residues in soils as amendments: Effect on the 636 mobility of two herbicides under different management practices. J. Environ. 637 Manage. (in press). doi:10.1016/j.jenvman.2018.07.045.

638 Marín-Benito, J.M., Brown, C.D., Herrero-Hernández, E., Arienzo, M., Sánchez639 Martín, M.J., Rodríguez-Cruz, M.S., 2013. Use of raw or incubated organic wastes 640 as amendments in reducing pesticide leaching through soil columns. Sci. Total 641 Environ. 463-464, 589-599. doi:10.1016/j.scitotenv.2013.06.051

642 Marín-Benito, J.M., Herrero-Hernández, E., Andrades, M.S., Sánchez-Martín, M.J., 643 Rodríguez-Cruz, M.S., 2014. Effect of different organic amendments on the 644 dissipation of linuron, diazinon and myclobutanil in an agricultural soil incubated 645 for different time periods. Sci. Total Environ. 476-477, 611-21. 646 doi:10.1016/j.scitotenv.2014.01.052

647 Martin-Laurent, F., Piutti, S., Hallet, S., Wagschal, I., Philippot, L., Catroux, G., Soulas, 648 G., 2003. Monitoring of atrazine treatment on soil bacterial, fungal and atrazine649 degrading communities by quantitative competitive PCR. Pest Manag. Sci. 59, 650 259-268. doi:10.1002/ps.630 
651 Nègre, M., Passarella, I., Boursier, C., Mozzetti, C., Gennari, M., 2006. Evaluation of 652 the bioavailability of the herbicide prosulfocarb through adsorption on soils and 653 model soil colloids, and through a simple bioassay. Pest Manag. Sci. 62, 957-964. 654 doi:10.1002/ps

655 Nyamwasa, I., Li, K., Rutikanga, A., Rukazambuga, D.N.T., Zhang, S., Yin, J., Ya656 zhong, C., Zhang, X.X., Sun, X., 2018. Soil insect crop pests and their integrated 657 management in East Africa: A review. Crop Prot. 106, 163-176.

658

Pascual, J.A., Garcia, C., Hernandez, T., Moreno, J.L., Ros, M., 2000. Soil microbial 660 activity as a biomarker of degradation and remediation processes. Soil Biol. 661 Biochem. 32, 1877-1883. doi:10.1016/S0038-0717(00)00161-9

662 Pose-Juan, E., Igual, J.M., Sánchez-Martín, M.J., Rodríguez-Cruz, M.S., 2017.

663 Influence of herbicide triasulfuron on soil microbial community in an unamended 664 soil and a soil amended with organic residues. Front. Microbiol. 8, 1-12. 665 doi:10.3389/fmicb.2017.00378

666 Pose-Juan, E., Sánchez-Martín, M.J., Andrades, M.S., Rodríguez-Cruz, M.S., Herrero667 Hernández, E., 2015. Pesticide residues in vineyard soils from Spain: Spatial and 668 temporal distributions. Sci. Total Environ. 514, 351-358.

669 doi:10.1016/j.scitotenv.2015.01.076

670 PPDB, 2018. Pesticide poperties data base. University of Hertfordshire. URL 671 https://sitem.herts.ac.uk/aeru/ppdb/en/index.htm (accessed 6.11.18). 
672 Rouchaud, J., Neus, O., Callens, D., Bulcke, R., 1997. Enhanced soil biodegradation of 673 prosulfocarb herbicide in barley crop. Bull. Environ. Contam. Toxicol. 58, 752757. doi:10.1007/s001289900397

675

676

677

678

679

680

681

682

683

684

685

686

687

688

690

691

692

Said-Pullicino, D., Gigliotti, G., Vella, A.J., 2004. Environmental fate of triasulfuron in soils amended with municipal waste compost. J. Environ. Qual. 33, 1743-1751. doi:10.2134/jeq2004.1743

Santás-Miguel, V., Cutillas-Barreiro, L., Arias-Estévez, M., Fernández-Sanjurjo, M.J., Álvarez-Rodríguez, E., Núñez-Delgado, A., Fernández-Calviño, D., 2018. Byproducts as an amendment of a mine soil: effects on microbial biomass determined using phospholipid fatty acids. Spanish J. Soil Sci. 8, 1-11. doi:10.3232/SJSS.2018.V8.N1.01

Sarmah, A.K., Kookana, R.S., Alston, A.M., 2000. Leaching and degradation of triasulfuron, metsulfuron-methyl, and chlorsulfuron in alkaline soil profiles under field conditions. Aust. J. Soil Res 38, 617-631. doi:10.1071/SR99114

Singh, S., Kumar, V., Chauhan, A., Datta, S., Wani, A.B., Singh, N., Singh, J., 2018. Toxicity, degradation and analysis of the herbicide atrazine. Environ. Chem. Lett. 16, 211-237. doi: 10.1007/s10311-017-0665-8

Sofo, A., Scopa, A., Dumontet, S., Mazzatura, A., Pasquale, V., 2012. Toxic effects of four sulphonylureas herbicides on soil microbial biomass. J. Environ. Sci. Heal. Part B Pestic. Food Contam. Agric. Wastes 47, 653-659. doi:10.1080/03601234.2012.669205 
693 Sparks, D.L., 1996. Methods of Soil Analysis. Part 3-Chemical Methods. Soil Science 694 Society of America, Inc., Madison, WI.

695 Stork, P.R., 1995. Field leaching and degradation of soil applied herbicides in a

696 gradationally textured alkaline soil: chlorsulfuron and triasulfuron. Aust. J. Agric.

$697 \quad$ Res. 46, 1445-1458.

698 Sun, D., Li, K., Bi, Q., Zhu, J., Zhang, Q., Jin, C., Lu, L., Lin, X., 2017. Effects of

699 organic amendment on soil aggregation and microbial community composition

700 during drying-rewetting alternation. Sci. Total Environ. 574, 735-743.

$701 \quad$ doi:10.1016/j.scitotenv.2016.09.112

702 Tortella, G.R., Mella-Herrera, R.A., Sousa, D.Z., Rubilar, O., Acuña, J.J., Briceño, G.,

703 Diez, M.C., 2013. Atrazine dissipation and its impact on the microbial communities

704 and community level physiological profiles in a microcosm simulating the

705 biomixture of on-farm biopurification system. J. Hazard. Mater. 260, 459-467.

706 doi:10.1016/j.jhazmat.2013.05.059

707 Valle, A., Boschin, G., Negri, M., Abbruscato, P., Sorlini, C., D’Agostina, A.,

708 Zanardini, E., 2006. The microbial degradation of azimsulfuron and its effect on the

709 soil bacterial community. J. Appl. Microbiol. 101, 443-452. doi:10.1111/j.1365-

710 2672.2006.02937.x

711 Vischetti, C., Monaci, E., Cardinali, A., Casucci, C., Perucci, P., 2008. The effect of

712 initial concentration, co-application and repeated applications on pesticide

713 degradation in a biobed mixture. Chemosphere 72, 1739-1743.

714 doi:10.1016/j.chemosphere.2008.04.065 
715 Wang, F., Zhu, L., Wang, X., Wang, J., Wang, J., 2015. Impact of repeated applications

716 of metalaxyl on its dissipation and microbial community in soil. Water. Air. Soil

717 Pollut. 226, 1-14. doi:10.1007/s11270-015-2686-x

718 Wu, X., Xu, J., Dong, F., Liu, X., Zheng, Y., 2014. Responses of soil microbial

719 community to different concentration of fomesafen. J. Hazard. Mater. 273, 155-

$720 \quad$ 164. doi:10.1016/j.jhazmat.2014.03.041

721 Zelles, L., 1999. Fatty acid patterns of phospholipids and lipopolysaccharides in the 722 characterisation of microbial communities in soil: a review. Biol. Fertil. Soils 29, 723 111-129. doi: 10.1007/s003740050533

724 Zhang, C., Xu, J., Liu, X., Dong, F., Kong, Z., Sheng, Y., Zheng, Y., 2010. Impact of 725 imazethapyr on the microbial community structure in agricultural soils.

726 Chemosphere 81, 800-806. doi:10.1016/j.chemosphere.2010.06.079 


\section{Figure captions:}

729 Fig. 1. Relative abundance (\% $\%$ ol) of PLFAs specifically diagnostics of Gram- and

730 Gram+ bacteria, Actinobacteria and fungi in the non-irrigated soils. Vertical bars

731 represent the standard deviation of three replicates. Different letters indicate significant

732 differences among treatments at the same sampling time (Tukey post hoc test, $p<0.05$ ).

733 S: unamended soil; $\mathrm{S}+\mathrm{GC} 1$ : amended soil with green compost 1; S+GC2: amended soil

734 with green compost 2; $\mathrm{H}$ : herbicides application. The first application of herbicides is

735 denoted by brown colour and the second application by purple colour.

736

737 Fig. 2. Relative abundance (\%mol) of PLFAs specifically diagnostics of Gram- and

738 Gram+ bacteria, Actinobacteria and fungi in the irrigated soils. Vertical bars represent

739 the standard deviation of three replicates. Different letters indicate significant

740 differences among treatments at the same sampling time (Tukey post hoc test, $p<0.05$ ).

741 S: unamended soil; $\mathrm{S}+\mathrm{GC} 1$ : amended soil with green compost 1; S+GC2: amended soil

742 with green compost 2; H: herbicides application; I: irrigation. The first application of

743 herbicides is denoted by brown colour and the second application by purple colour.

745 Fig. 3. Principal components analysis (PCA) of non-irrigated (A, B, C) and irrigated (D,

746 E, F) soils showing loading scores for Gram- and Gram+ bacteria, Actinobacteria and

747 fungi, and the scores of sampling times ( 0 days: circle; 28 days: inverse triangle; 69

748 days: square; 97 days: star; 124 days: triangle; 215 days: diamond) on the two main

749 components. The application of herbicides is denoted by dark colors, the non-

750 application of herbicides by light colors in unamended soil (Red), GC1-amended soil

751 (Blue) and GC2-amended soil (Green). Percent variability explained by each principal

752 component is shown in parentheses after each axis legend. 

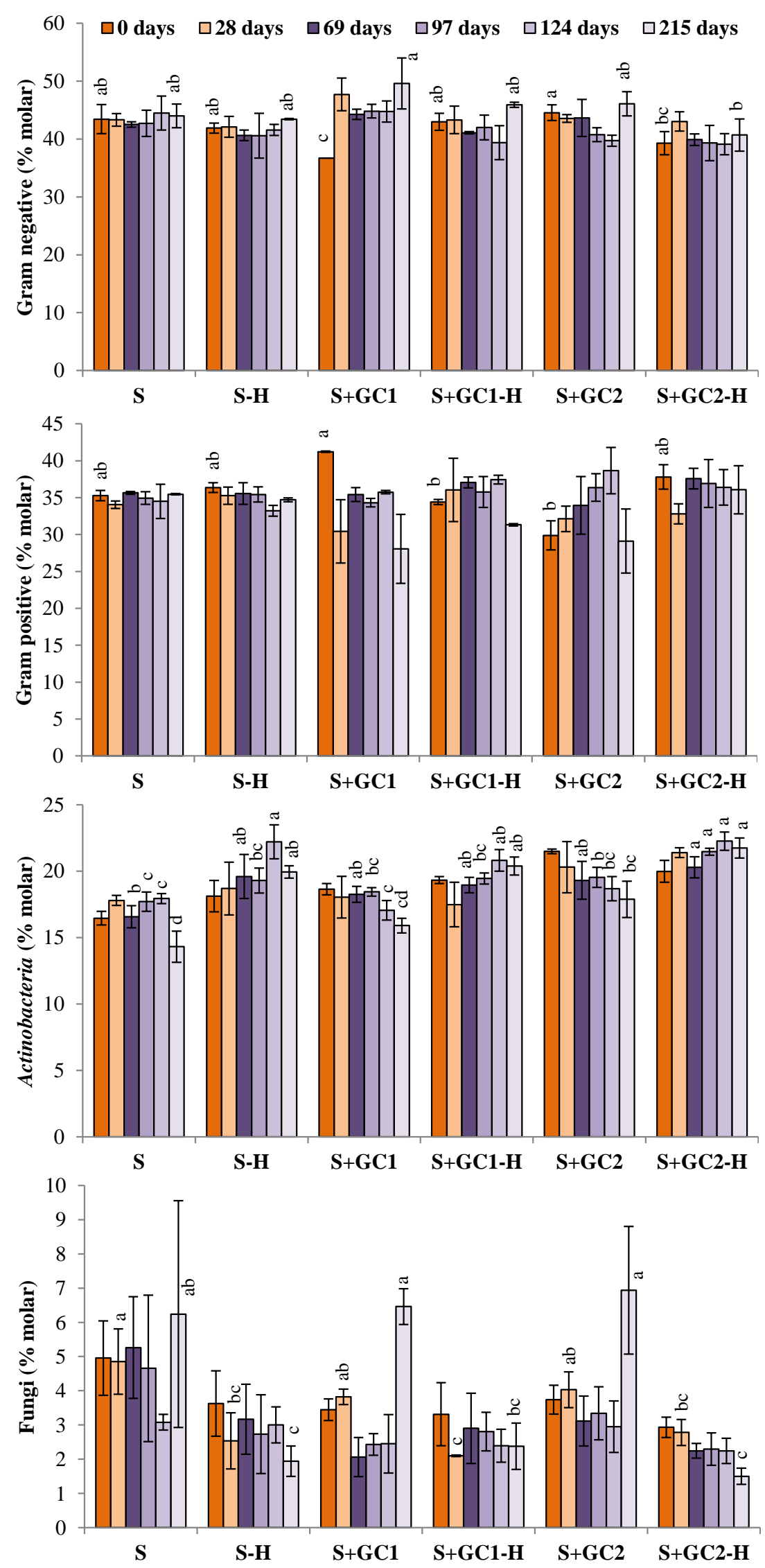

Figure 1 

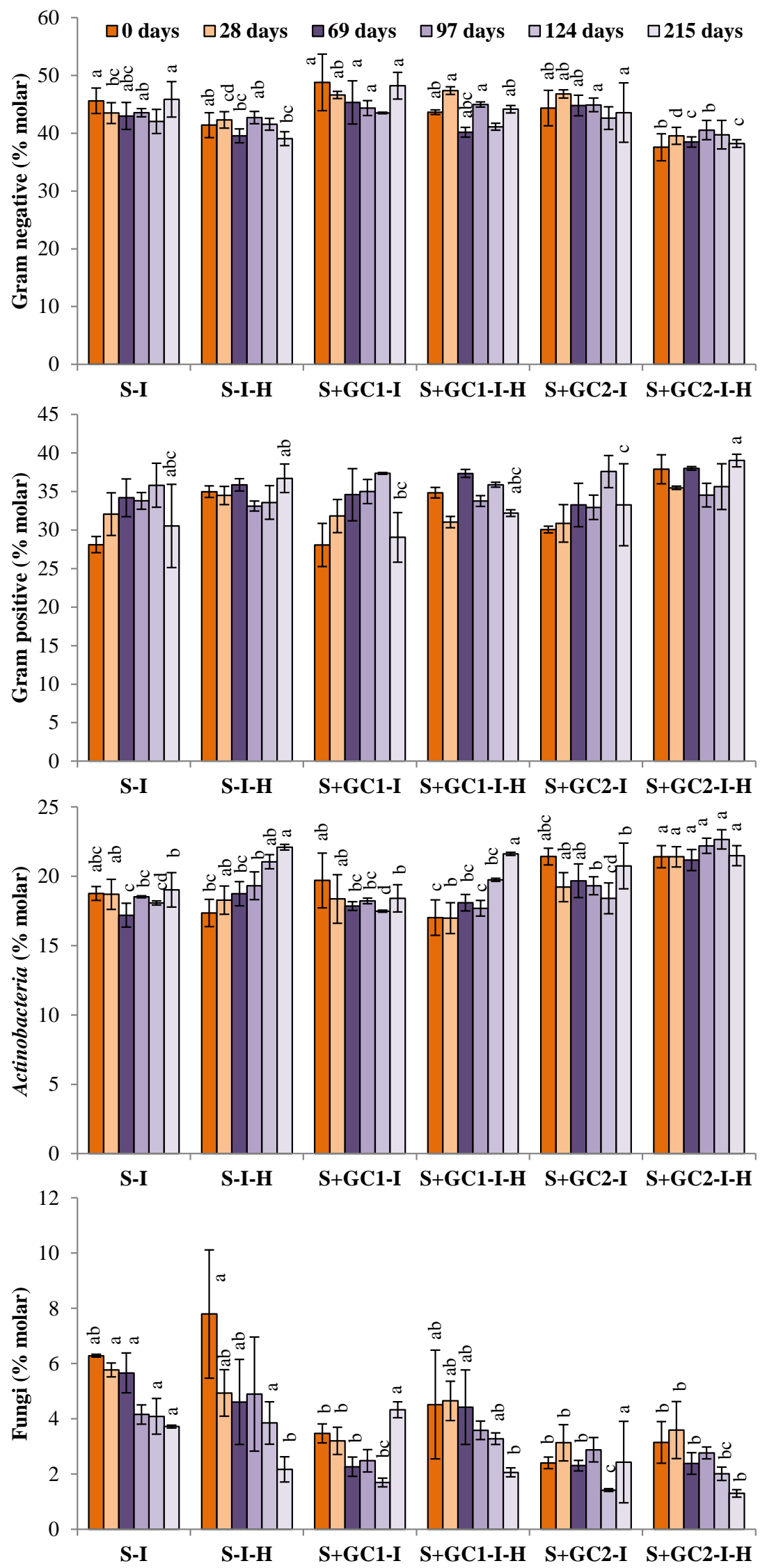

Figure 2 
A

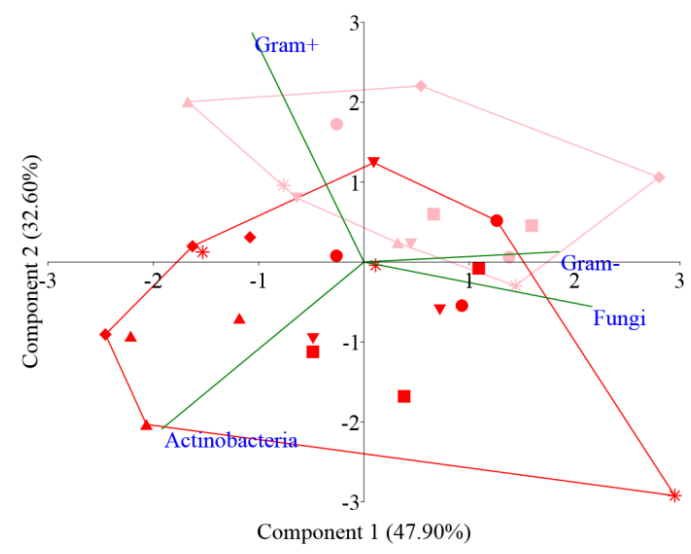

B

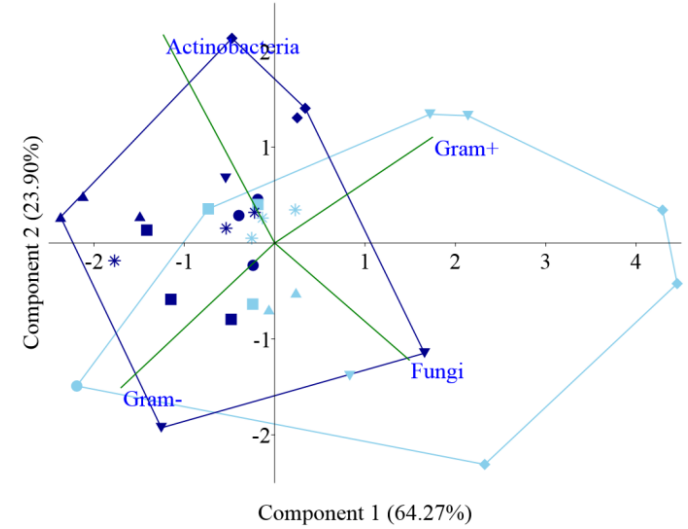

C

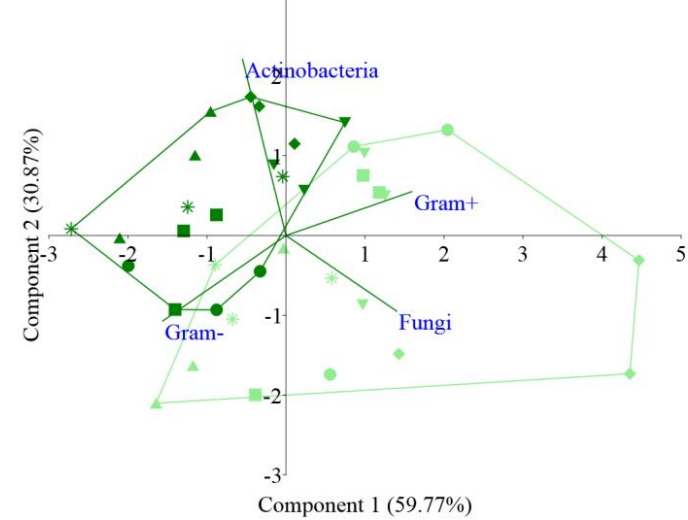

D

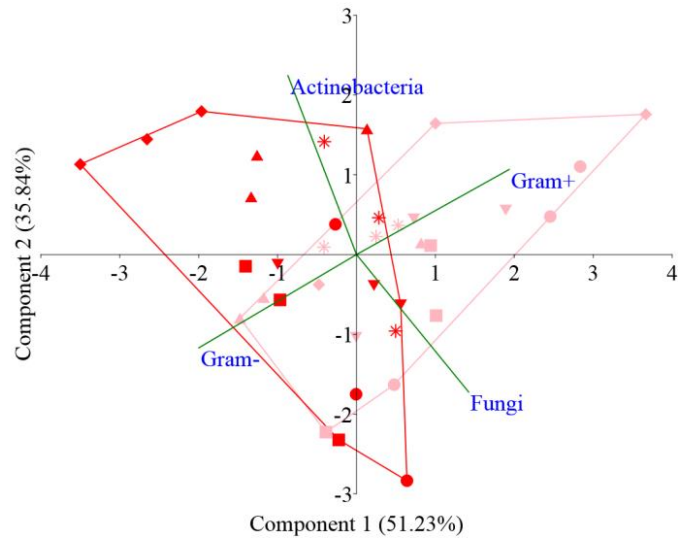

E

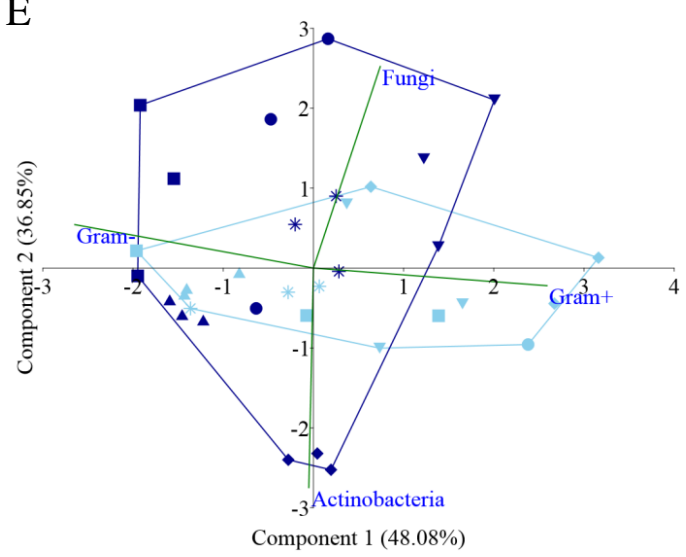

F

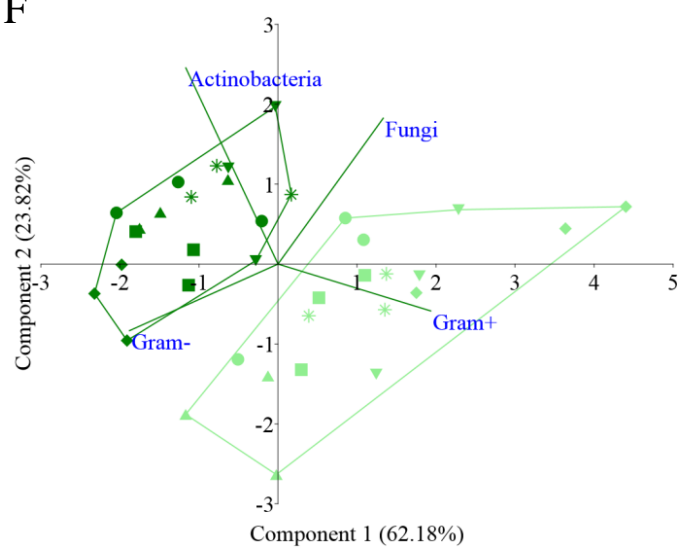

Figure 3 
Table 1. Characteristics of unamended and GC amended soils, non-irrigated or irrigated (I) after the first and the second application of herbicides in the field plots (sampling times corresponding to 13 days and 84 days after the beginning of the experiment).

\begin{tabular}{llllll}
\hline & $\mathrm{pH}$ & $\mathrm{OC}^{\mathrm{a}}(\%)$ & $\mathrm{DOC}^{\mathrm{b}}\left(\mathrm{mg} \mathrm{kg}^{-1}\right)$ & $\mathrm{N}(\%)$ & $\mathrm{C} / \mathrm{N}$ \\
\hline Soil & $7.10-6.71$ & $1.41-0.98$ & $0.057-0.045$ & $0.12-0.08$ & $11.8-12.2$ \\
Soil-I & $7.12-6.77$ & $1.22-1.05$ & $0.051-0.041$ & $0.11-0.10$ & $11.1-10.5$ \\
Soil+GC1 & $7.69-7.59$ & $2.29-2.09$ & $0.084-0.106$ & $0.19-0.21$ & $12.1-9.95$ \\
Soil+GC1-I & $7.55-7.51$ & $2.17-2.07$ & $0.060-0.088$ & $0.20-0.20$ & $10.85-10.4$ \\
Soil+GC2 & $7.24-7.47$ & $4.81-3.75$ & $0.322-0.324$ & $0.43-0.33$ & $11.2-11.4$ \\
Soil+GC2-I & $7.18-7.41$ & $5.87-4.32$ & $0.482-0.413$ & $0.46-0.37$ & $12.8-11.7$ \\
\hline
\end{tabular}

${ }^{\mathrm{a}}$ Organic carbon; ${ }^{\mathrm{b}}$ Dissolved organic carbon. 
Table 2: Pearson correlation coefficients of non-irrigated soils between population of Gram-, Gram+, Actinobacteria, fungi and their corresponding relative concentrations, total biomass, ratio Gram-/ total Gram+, ratio bacteria/fungi, remaining concentrations of triasulfuron (TSF) and prosulfocarb (PSC) and remaining percentage of TSF and PSC. Significant correlations were denoted by asterisks and blond font.

\begin{tabular}{|c|c|c|c|c|c|c|c|c|c|c|c|c|c|c|c|}
\hline No irrigation & $\begin{array}{l}\text { Gram- } \\
(\mathrm{nmol} / \mathrm{g})\end{array}$ & $\begin{array}{l}\text { Gram + } \\
(\mathrm{nmol} / \mathrm{g})\end{array}$ & $\begin{array}{l}\text { Actinobacteria } \\
(\mathrm{nmol} / \mathrm{g})\end{array}$ & $\begin{array}{l}\text { Fungi } \\
(\mathrm{nmol} / \mathrm{g})\end{array}$ & $\begin{array}{l}\text { Biomass } \\
(\mathrm{nmol} / \mathrm{g})\end{array}$ & $\begin{array}{l}\text { Gram - I } \\
\text { Gram + }\end{array}$ & $\begin{array}{l}\text { Bacteria } \\
\text { / Fungi }\end{array}$ & $\begin{array}{l}\text { Gram- } \\
(\%)\end{array}$ & $\begin{array}{l}\text { Gram+ } \\
(\%)\end{array}$ & $\begin{array}{l}\text { Actinobacteria } \\
(\%)\end{array}$ & $\begin{array}{l}\text { Fungi } \\
(\%)\end{array}$ & {$[\mathrm{TSF}]$} & {$[\mathrm{PSC}]$} & $\begin{array}{l}\text { TSF } \\
(\%)\end{array}$ & $\begin{array}{l}\text { PSC } \\
(\%)\end{array}$ \\
\hline Gram- (nmol/g) & 1 & & & & & & & & & & & & & & \\
\hline Gram + (nmol/g) & $0.960^{* * * *}$ & 1 & & & & & & & & & & & & & \\
\hline Actinobacteria (nmol/g) & 0.936 ***** & $0.952^{* * * *}$ & 1 & & & & & & & & & & & & \\
\hline Fungi (nmol/g) & $0.576^{* * *}$ & $0.575^{* * * *}$ & $0.506^{* * * *}$ & 1 & & & & & & & & & & & \\
\hline Biomass (nmol/g) & 0.986 **** & $0.989^{* * * *}$ & $0.966^{* * * *}$ & $0.604^{* * *}$ & 1 & & & & & & & & & & \\
\hline Gram- / Gram + & $-0.313^{*}$ & $-0.535^{* * * *}$ & $-0.551^{* * *}$ & -0.257 & $-0.455^{* *}$ & 1 & & & & & & & & & \\
\hline Bacteria / Fungi & -0.169 & -0.149 & -0.077 & $-0.740^{* * *}$ & -0.177 & -0.021 & 1 & & & & & & & & \\
\hline Gram- (\%) & $-0.288^{*}$ & $-0.510^{\text {**** }}$ & $-0.505^{* * * *}$ & $-0.422^{* *}$ & $-0.435^{* *}$ & $0.970^{* * * *}$ & 0.168 & 1 & & & & & & & \\
\hline Gram + (\%) & $0.535^{* * *}$ & $0.733^{* * * *}$ & $0.600^{* * * *}$ & $0.301^{*}$ & $0.634^{* * *}$ & $-0.789^{* * * *}$ & 0.020 & $-0.765^{* * *}$ & 1 & & & & & & \\
\hline Actinobacteria (\%) & $-0.318^{* *}$ & $-0.344^{*}$ & -0.087 & $-0.504^{* * *}$ & $-0.331^{*}$ & -0.243 & $-0.390^{* * *}$ & -0.187 & -0.256 & 1 & & & & & \\
\hline Fungi (\%) & 0.172 & 0.145 & 0.041 & $0.669^{* * * *}$ & 0.158 & 0.067 & $-0.952^{* * * *}$ & -0.053 & 0.02 & $-0.401^{* *}$ & 1 & & & & \\
\hline [TSF] & $0.652^{* * *}$ & $0.651^{* * * *}$ & $0.609^{* * * *}$ & $0.478^{* * *}$ & $0.659^{* * *}$ & -0.261 & -0.247 & 0.266 & $0.412^{* *}$ & $-0.330^{*}$ & $0.283^{*}$ & 1 & & & \\
\hline [PSC] & $0.602^{* * * *}$ & $0.597^{* * *}$ & $0.573^{* * *}$ & $0.368^{* *}$ & $0.605^{* *}$ & -0.220 & -0.223 & -0.212 & $0.341^{*}$ & -0.207 & $0.301^{*}$ & $0.811^{* * *}$ & 1 & & \\
\hline$\% \mathrm{TSF}$ & $0.614^{* * * *}$ & $0.624^{* * * *}$ & $0.570^{* * * *}$ & $0.535^{* * *}$ & $0.639^{* * *}$ & -0.196 & $-0.362^{*}$ & -0.217 & $0.359^{\text {** }}$ & $-0.378^{* * *}$ & $0.406^{* * *}$ & $0.895^{* * *}$ & $0.867^{* * * *}$ & 1 & \\
\hline$\% \mathrm{PSC}$ & $0.627^{* * * *}$ & $0.612^{* * * *}$ & $0.574^{* * * *}$ & $0.498^{* * *}$ & $0.628^{* * * *}$ & -0.196 & $-0.370^{*}$ & -0.219 & $0.337^{*}$ & $-0.290^{*}$ & $0.404^{* * *}$ & $0.863^{* * * *}$ & $0.919^{* * * *}$ & $0.930^{* * * *}$ & 1 \\
\hline
\end{tabular}


Table 3: Pearson correlation coefficients of irrigated soils between population of Gram-, Gram+, Actinobacteria, fungi and their corresponding relative concentrations, total biomass, ratio Gram-/ total Gram+, ratio bacteria/fungi, remaining concentrations of triasulfuron (TSF) and prosulfocarb (PSC), and remaining percentage of TSF and PSC. Significant correlations were denoted by asterisks and blond font.

\begin{tabular}{|c|c|c|c|c|c|c|c|c|c|c|c|c|c|c|c|}
\hline Irrigation & $\begin{array}{l}\text { Gram- } \\
(\mathrm{nmol} / \mathrm{g})\end{array}$ & $\begin{array}{l}\text { Gram + } \\
(\mathrm{nmol} / \mathrm{g})\end{array}$ & $\begin{array}{l}\text { Actinobacteria } \\
(\mathrm{nmol} / \mathrm{g})\end{array}$ & $\begin{array}{l}\text { Fungi } \\
(\mathrm{nmol} / \mathrm{g})\end{array}$ & $\begin{array}{l}\text { Biomass } \\
(\mathrm{nmol} / \mathrm{g})\end{array}$ & $\begin{array}{l}\text { Gram - I } \\
\text { Gram + }\end{array}$ & $\begin{array}{l}\text { Bacteria } \\
\text { / Fungi }\end{array}$ & $\begin{array}{l}\text { Gram- } \\
(\%)\end{array}$ & $\begin{array}{l}\text { Gram+ } \\
(\%)\end{array}$ & $\begin{array}{l}\text { Actinobacteria } \\
(\%)\end{array}$ & $\begin{array}{l}\text { Fungi } \\
(\%)\end{array}$ & [TSF] & {$[\mathrm{PSC}]$} & $\begin{array}{l}\text { TSF } \\
(\%)\end{array}$ & $\begin{array}{l}\text { PSC } \\
(\%)\end{array}$ \\
\hline Gram- (nmol/g) & 1 & & & & & & & & & & & & & & \\
\hline Gram + (nmol/g) & $0.937^{* * *}$ & 1 & & & & & & & & & & & & & \\
\hline Actinobacteria $(\mathrm{nmol} / \mathrm{g})$ & $0.865^{* * *}$ & $0.963^{* * * *}$ & 1 & & & & & & & & & & & & \\
\hline Fungi (nmol/g) & $0.763^{* * *}$ & $0.652^{* * * *}$ & $0.520^{* * * *}$ & 1 & & & & & & & & & & & \\
\hline Biomass (nmol/g) & $0.977^{* * *}$ & $0.986^{* * *}$ & $0.939^{* * * *}$ & $0.738^{* * * *}$ & 1 & & & & & & & & & & \\
\hline Gram- / Gram + & 0.019 & $-0.311^{*}$ & $-0.436 * *$ & 0.163 & -0.176 & 1 & & & & & & & & & \\
\hline Bacteria / Fungi & $-0.420^{* *}$ & -0.230 & -0.120 & $-0.710^{* * * *}$ & $-0.342^{*}$ & $-0.481^{* * * *}$ & 1 & & & & & & & & \\
\hline Gram- $(\%)$ & -0.088 & $-0.413^{* *}$ & $-0.505^{* * *}$ & -0.071 & $-0.291^{*}$ & $0.963^{* * *}$ & $-0.302^{*}$ & 1 & & & & & & & \\
\hline Gram + (\%) & $0.305^{*}$ & $0.595^{* * *}$ & $0.617^{* * * *}$ & -0.011 & $460^{* *}$ & $-0.854^{* * *}$ & $0.425^{* *}$ & $-0.844^{* * * *}$ & 1 & & & & & & \\
\hline Actinobacteria (\%) & $-0.620^{* * *}$ & $-0.400^{* *}$ & -0.183 & $-0.705^{* * *}$ & $-0.497^{* * *}$ & $-0.652^{* * * *}$ & $0.665^{* * *}$ & $-0.492^{* * * *}$ & 0.250 & 1 & & & & & \\
\hline Fungi (\%) & $0.433^{* *}$ & 0.273 & 0.134 & $0.906^{* * * *}$ & $0.380^{* *}$ & $0.447^{* *}$ & $-0.856^{* * * *}$ & 0.232 & $-0.355^{* *}$ & $-0.723^{* * * *}$ & 1 & & & & \\
\hline [TSF] & $0.782^{* * *}$ & $0.778^{* * * *}$ & $0.701^{* * *}$ & $0.667^{* * * *}$ & $0.795^{* * *}$ & -0.035 & $-0.476^{* * * *}$ & -0.151 & 0.247 & $-0.491^{\text {**** }}$ & $0.413^{* *}$ & 1 & & & \\
\hline [PSC] & $0.670^{* * *}$ & $0.733^{* * *}$ & $0.731^{* * *}$ & $0.420^{* *}$ & $0.716^{* *}$ & -0.230 & -0.248 & $-0.293^{*}$ & $0.373^{* *}$ & -0.211 & 0.188 & $0.795^{* * * *}$ & 1 & & \\
\hline$\% \mathrm{TSF}$ & $0.775^{* * *}$ & $0.782^{* * * *}$ & $0.750^{* * * *}$ & $0.623^{* * * *}$ & $0.797^{* * *}$ & -0.087 & $-0.474^{* * * *}$ & -0.198 & 0.262 & $-0.403^{* *}$ & $0.390^{* * *}$ & $0.904^{* * *}$ & $0.903^{* * *}$ & 1 & \\
\hline$\%$ PSC & $0.770^{* * * *}$ & $0.811^{* * * *}$ & $0.777^{* * *}$ & $0.601^{* * * *}$ & $0.809^{* * * *}$ & -0.183 & $-0.360^{*}$ & $-0.277^{*}$ & $0.350^{* *}$ & $-0.346^{*}$ & $0.316^{*}$ & $0.875^{* * *}$ & $0.942^{* * * *}$ & $0.952^{\text {**** }}$ & 1 \\
\hline
\end{tabular}




\section{SUPPLEMENTARY MATERIAL}

\section{INFLUENCE OF DIFFERENT AGRICULTURAL MANAGEMENT PRACTICES \\ ON SOIL MICROBIAL COMMUNITY OVER DISSIPATION TIME OF TWO \\ HERBICIDES}

Carlos García-Delgado, Víctor Barba-Vicente, Jesús M. Marín-Benito, J. Mariano Igual, María J. Sánchez-Martín, M. Sonia Rodríguez-Cruz*

Instituto de Recursos Naturales y Agrobiología de Salamanca (IRNASA-CSIC), Cordel de Merinas 40-52, 37008 Salamanca, Spain.

*Corresponding author.

E-mail address: msonia.rodriguez@irnasa.csic.es

Tel.: +34 923219606. Fax: +34923219609

Number of Pages: 11

Number of Tables: 3

Number of Figures: 3 


\section{Soil sampling and sample processing}

Surface soil samples from 0 to $10 \mathrm{~cm}$ were collected on the first day after herbicide application ( 0 days), and at different times up to 215 days after treatment to determine herbicide dissipation and at 0,28, 69, 97, 124 and 215 days to determine soil phospholipid fatty acids (PLFAs) in all the treatments. Five sub-samples were taken in each plot, mixing them before they were transferred to polypropylene bottles. All the samples were transported to the laboratory in portable refrigerators. The soil water content of the bulk sample for each 10 -cm soil layer was gravimetrically determined by weight difference, measuring the soil sample mass before and after drying at $110^{\circ} \mathrm{C}$ for 24 h. Soil samples, previously air-dried overnight if necessary, were then sieved $(<2$ mm) and their characteristics determined by standard methods (Sparks, 1996). The pH of the soils was determined in soil/water suspensions (1:2.5). The organic carbon (OC) content was determined by the modified Walkley-Black method. The dissolved organic carbon (DOC) content was determined in a suspension of soil in deionized water (1:2) after shaking $(24 \mathrm{~h})$, centrifugation (20 min at $10000 \mathrm{rpm})$, and filtering using a Shimadzu 5050 organic carbon analyser (Shimadzu, Columbia, MD, USA). Total N content was determined by the Kjeldahl method. Particle size distribution was determined using the pipette method. Soil samples to determine herbicide dissipation were analyzed immediately. To determine PLFAs, the samples were frozen at $-80^{\circ} \mathrm{C}$ and lyophilized prior to extraction and analysis.

\section{Herbicide extraction and analysis}

Duplicate subsamples of moist soil $(6 \mathrm{~g})$ from each plot were transferred to a glass tube, and extracted with methanol $(12 \mathrm{~mL})$. The samples were sonicated for $1 \mathrm{~h}$, shaken at $20^{\circ} \mathrm{C}$ for $24 \mathrm{~h}$, and then centrifuged at $5045 \mathrm{~g}$ for $15 \mathrm{~min}$. A volume of $8 \mathrm{~mL}$ was transferred to a clean glass tube and evaporated until dryness at $25^{\circ} \mathrm{C}$ under a nitrogen 
stream using an EVA-EC2-L evaporator (VLM GmbH, Bielefeld, Germany). The residue was dissolved in $0.5 \mathrm{~mL}$ of methanol+formic acid (1\%), filtered to remove particles $>0.45$ $\mu \mathrm{m}$ in a GHP Acrodisc filter (Waters Corporation), and transferred to a HPLC glass vial for analysis (Marín-Benito et al., 2018).

The analysis of triasulfuron and prosulfocarb was performed by HPLC. The apparatus used was a Waters chromatograph (Waters Assoc., Milford, MA, USA), equipped with a model e2695 multisolvent delivery and autosampler system attached to a ZQ mass spectrometer detector (MS), with Empower software as the data acquisition and processing system. A Luna ${ }^{\circledR} 3 \mu \mathrm{m} \operatorname{PFP}(2) 100 \AA(150 \times 4.6 \mathrm{~mm})$ column by Phenomenex (Torrance, CA, USA) was used at ambient temperature, and the mobile phase was acetonitrile:water+1\% formic acid (70:30). The flow rate of the mobile phase was $0.4 \mathrm{~mL}$ $\min ^{-1}$, and the sample injection volume was $10 \mu \mathrm{L}$. Detection involved monitoring the positive molecular ion $[\mathrm{m} / \mathrm{z}] 402.8[\mathrm{M}+\mathrm{H}]^{+}$(triasulfuron) and $252.4[\mathrm{M}+\mathrm{H}]^{+}$(prosulfocarb) $^{2}$ after applying an optimized cone voltage of $20 \mathrm{~V}$, and the retention times were $6.1 \mathrm{~min}$ and 14.1 min, respectively (Marín-Benito et al., 2018).

The matrix-matched calibration standards were between 0.1 and $2.5 \mu \mathrm{g} \mathrm{mL} L^{-1}$ for both herbicides, and the limit of detection (LOD) and limit of quantification (LOQ) were in the ranges $0.018-0.026 \mu \mathrm{g} \mathrm{mL}^{-1}$ or $0.059-0.088 \mu \mathrm{g} \mathrm{mL}^{-1}$ for triasulfuron, and $0.005-0.008$ $\mu \mathrm{g} \mathrm{mL} L^{-1}$ or $0.017-0.027 \mu \mathrm{g} \mathrm{mL}{ }^{-1}$ for prosulfocarb in the unamended and amended soils, respectively. The method's recoveries were determined by spiking three unamended and amended soil samples with triasulfuron $\left(76.9 \mu \mathrm{g} \mathrm{kg}^{-1}\right)$ or prosulfocarb $\left(3.46 \mathrm{mg} \mathrm{kg}^{-1}\right)$ and performing the extraction procedure as described above. The mean recoveries of triasulfuron and prosulfocarb were $>80 \%$ for the unamended and GC-amended soils. The amounts of triasulfuron and prosulfocarb extracted from soils were not corrected for 
recovery values because matrix-matched calibration method was used (Marín-Benito et al., 2018).

\section{Dissipation kinetics}

The dissipation kinetics for both herbicides was fitted to a single first-order (SFO) kinetic model $\left(\mathrm{C}=\mathrm{C}_{0} \mathrm{e}^{-\mathrm{kt}}\right)$ or first order multicompartment $(\mathrm{FOMC})$ model $\left(\mathrm{C}=\mathrm{C}_{0} /(\mathrm{t} / \beta)+\right.$ $1)^{\alpha}$ ), known also as the Gustafson and Holden model. FOCUS work group guidance recommendations were followed (FOCUS, 2006) for selecting the kinetic model that best describes the dissipation results. The coefficient of determination $\left(\mathrm{R}^{2}\right)$ and the chi-square

$\left(\chi^{2}\right)$ test were calculated as indicators of the goodness of fit. The $\chi^{2}$ test considers the deviations between observed and calculated values relative to the uncertainty of the measurements for a specific fit, and was used to compare the goodness of fit of the two models tested. The error value at which the $\chi^{2}$ test is fulfilled at a given degree of freedom should be below $15 \%$ (at a 5\% significance level). Values for the time to $50 \%$ dissipation $\left(\mathrm{DT}_{50}\right)$ were used to characterize the decay curves and compare variations in dissipation rates. The parameters of the kinetic models were estimated using the Excel Solver add-in package (FOCUS, 2006).

\section{References}

FOCUS, 2006. Guidance document on estimating persistence and degradation kinetics from environmental fate studies on pesticide in EU registration. Report of the FOCUS Work Group on Degradaton Kinetics, EC Document Reference Sanco/10058/2005 version 2.0.

Marín-Benito, J.M., Barba, V., Ordax, J.M., Andrades, M.S., Sánchez-Martín, M.J., Rodríguez-Cruz, M.S., 2018. Application of green compost as amendment in an 
agricultural soil: Effect on the behaviour of triasulfuron and prosulfocarb under field conditions. J. Environ. Manage. 207, 180-191.

Sparks, D.L., 1996. Methods of Soil Analysis. Part 3-Chemical Methods. Soil Science Society of America, Inc., Madison, WI. 
Table S1. Results of PERMANOVA of the effect of herbicides application $(\mathrm{H})$, sampling time (T), soil treatment (ST) and their interaction on the relative abundance (\%mol) of PLFAs specific for Gram positive and negative bacteria, Actinobacteria and fungi in unamended and amended soils.

\begin{tabular}{|c|c|c|c|c|c|}
\hline \multicolumn{3}{|c|}{ Non-Irrigation } & \multicolumn{3}{|l|}{ Irrigation } \\
\hline & F-value & $p$-value & & F-value & $p$-value \\
\hline Soil & & & Soil & & \\
\hline Herbicide & 8.811 & 0.0001 & Herbicide & 7.235 & 0.0017 \\
\hline Time & 0.9423 & 0.5235 & Time & 1.192 & 0.3059 \\
\hline $\mathrm{H} * \mathrm{~T}$ & -0.1369 & 0.4663 & $\mathrm{H} * \mathrm{~T}$ & 2.247 & 0.0340 \\
\hline GC1 & & & GC1 & & \\
\hline Herbicide & 5.772 & 0.0127 & Herbicide & 3.071 & 0.0664 \\
\hline Time & 3.710 & 0.0057 & Time & 4.741 & 0.0004 \\
\hline $\mathrm{H} * \mathrm{~T}$ & 0.5160 & 0.0306 & $\mathrm{H} * \mathrm{~T}$ & 1.627 & 0.0009 \\
\hline GC2 & & & GC2 & & \\
\hline Herbicide & 6.520 & 0.0082 & Herbicide & 32.87 & 0.0001 \\
\hline Time & 3.103 & 0.0092 & Time & 0.6189 & 0.7198 \\
\hline $\mathrm{H} * \mathrm{~T}$ & 1.977 & 0.0811 & $\mathrm{H} * \mathrm{~T}$ & 4.175 & 0.0044 \\
\hline Global & & & Global & & \\
\hline Herbicide & 15.37 & 0.0001 & Herbicide & 26.69 & 0.0001 \\
\hline Time & 5.067 & 0.0001 & Time & 2.819 & 0.0061 \\
\hline ST & 3.409 & 0.0110 & ST & 6.398 & 0.0003 \\
\hline $\mathrm{H}^{*} \mathrm{~T}$ & 1.899 & 0.0060 & $\mathrm{H} * \mathrm{~T}$ & 3.124 & 0.0001 \\
\hline $\mathrm{H} * \mathrm{ST}$ & -0.8854 & 0.2920 & $\mathrm{H} * \mathrm{ST}$ & 3.123 & 0.0021 \\
\hline $\mathrm{T} * \mathrm{ST}$ & 0.2592 & 0.2448 & $\mathrm{~T} * \mathrm{ST}$ & -0.7416 & 0.7282 \\
\hline
\end{tabular}




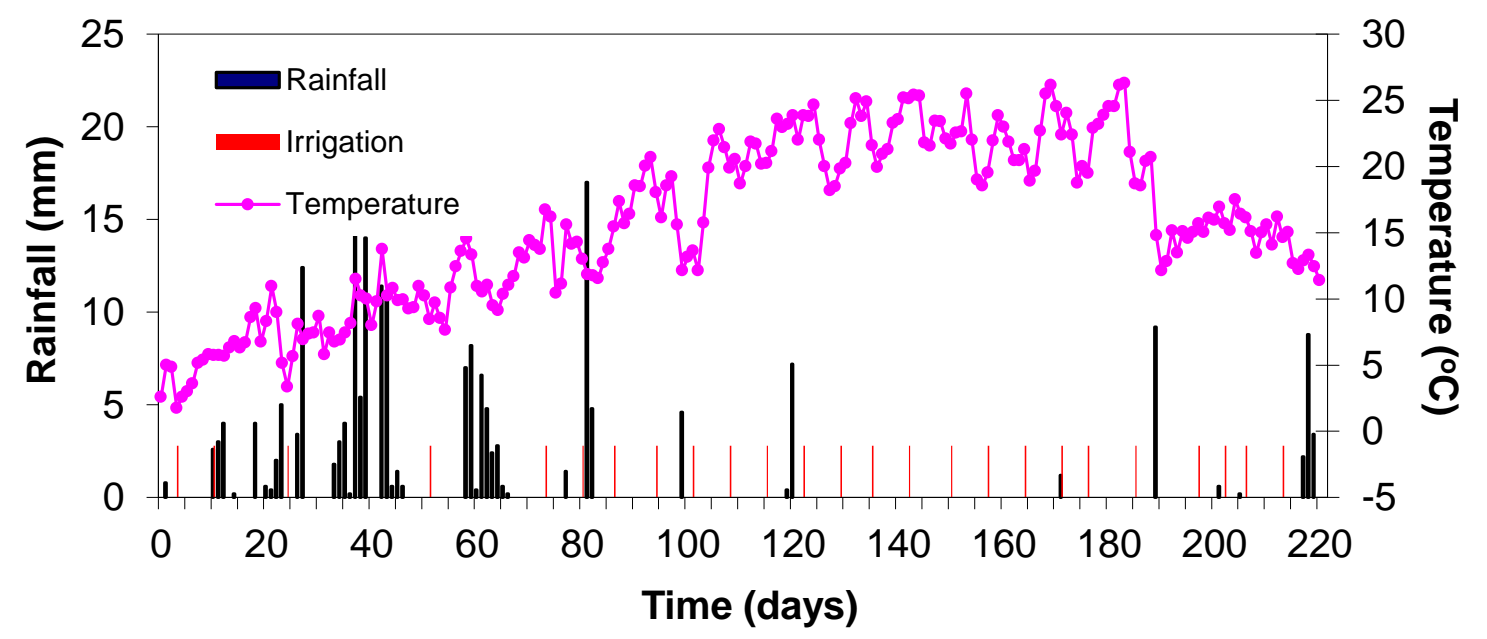

Fig. S1. Rainfall, additional irrigation and temperature evolution over time of experiment. 

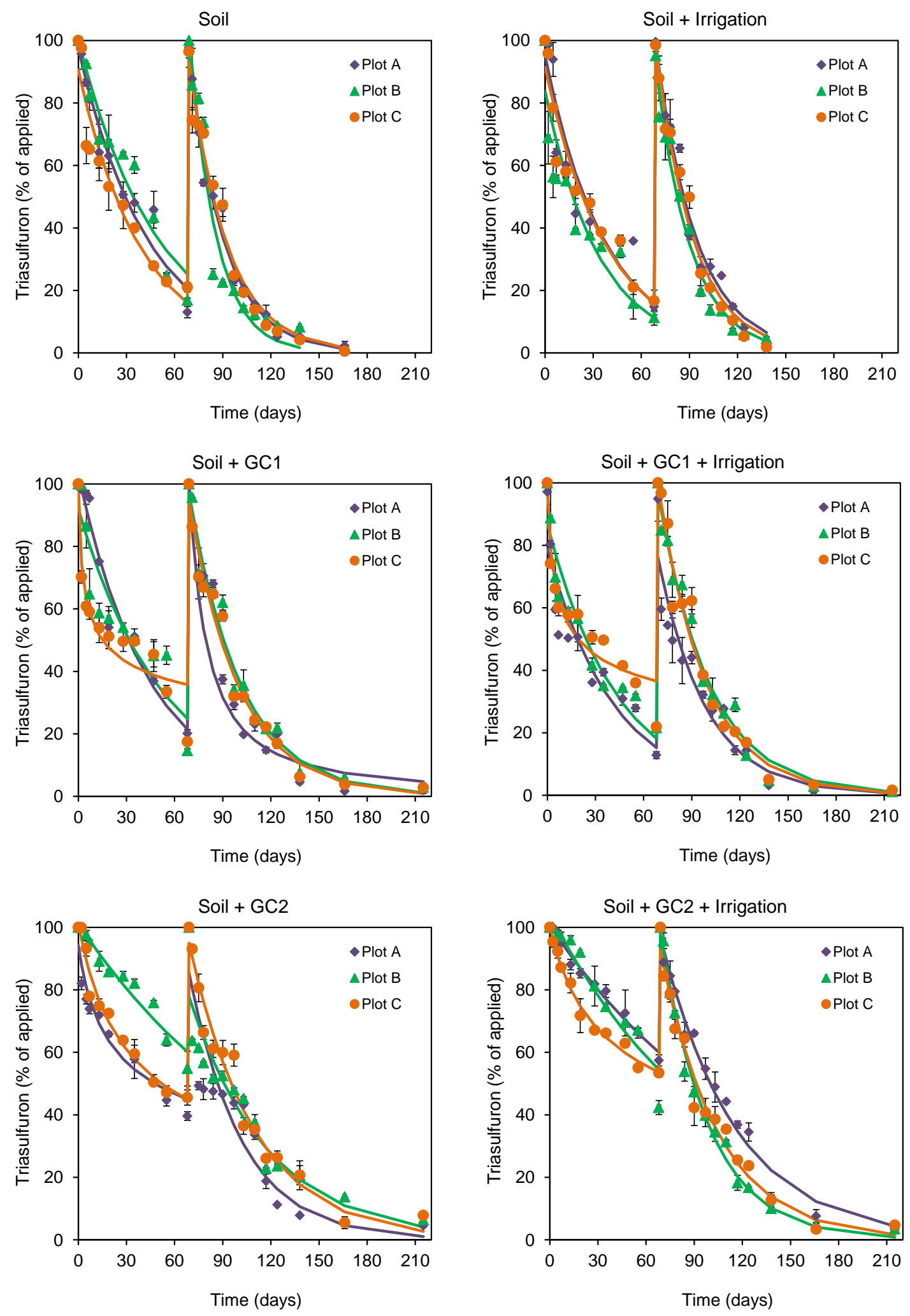

Fig. S2. Dissipation kinetics of triasulfuron in unamended soil and soil amended with green compost ( $\mathrm{GC} 1$ and $\mathrm{GC} 2$ ) after the first application (0 - 68 days) and after the second application (69 - 215 days). Error bars represent the standard deviation of the mean values of plots treated with the herbicide $(n=3)$. 

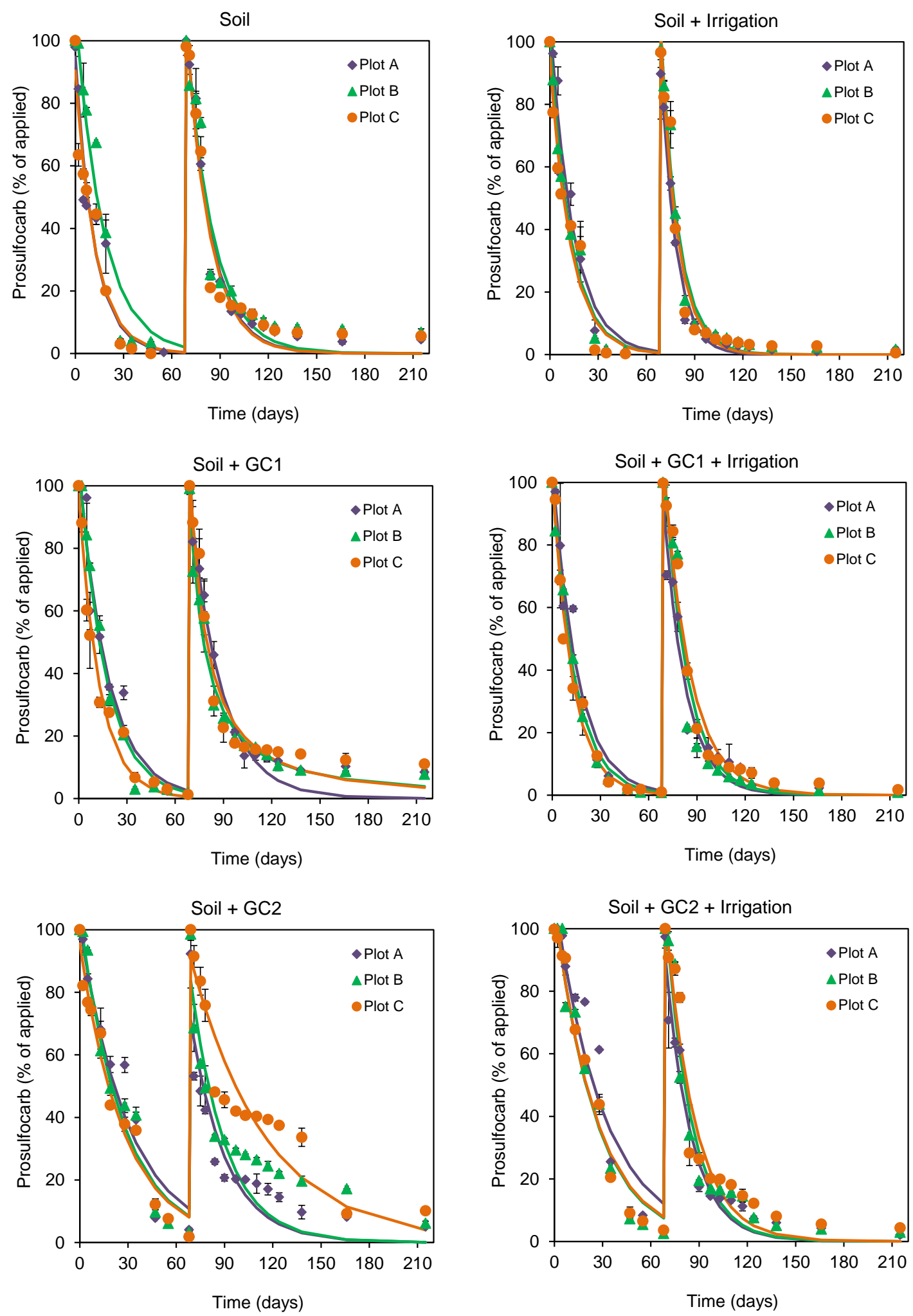

Fig S3. Dissipation kinetics of prosulfocarb in unamended soil and soil amended with green compost (GC1 and GC2) after the first application (0 - 68 days) and after the second application (69 - 215 days). Error bars represent the standard deviation of the mean values of plots treated with the herbicide $(n=3)$. 

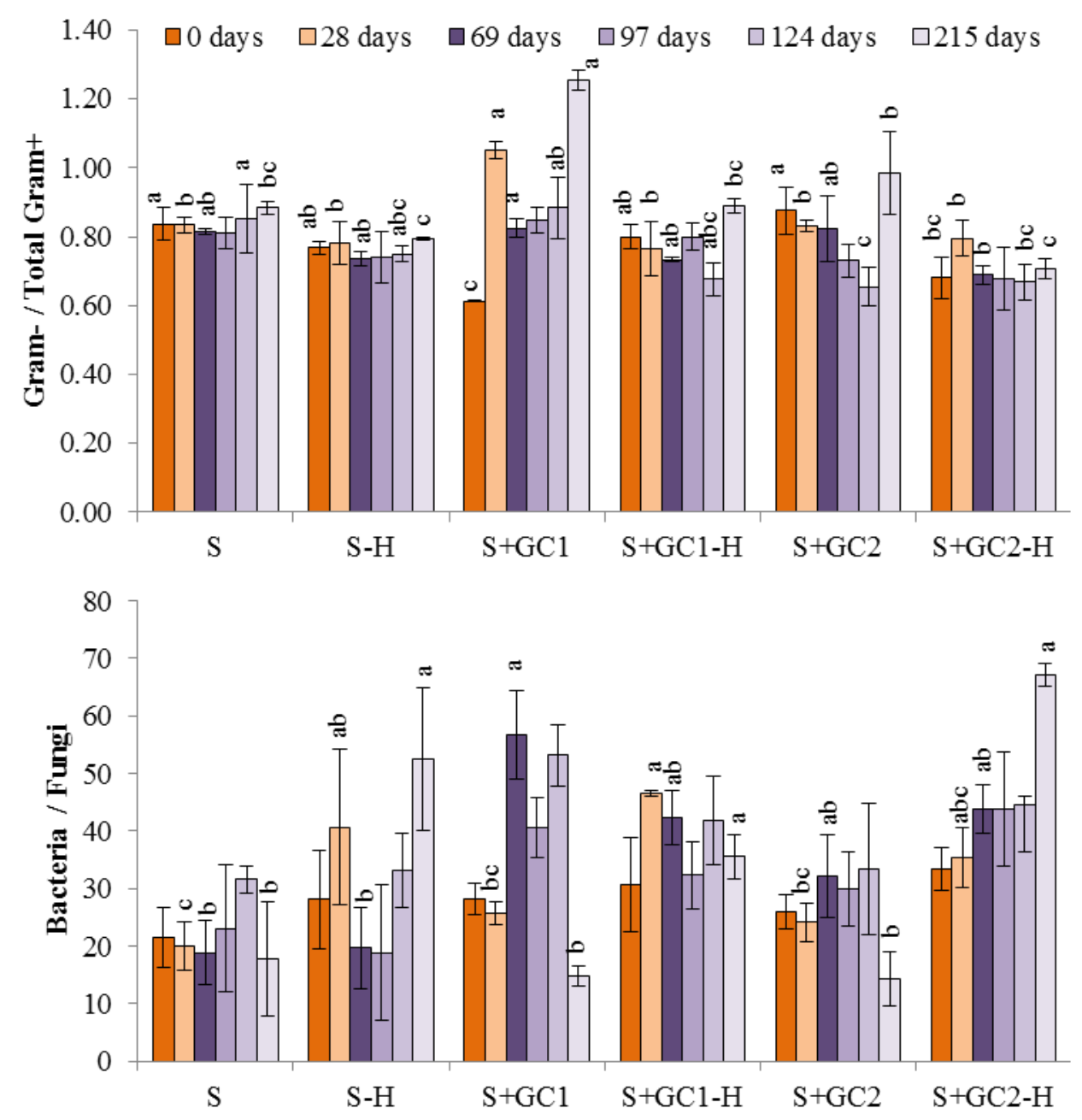

Fig S4. Ratio Gram- / total Gram+ bacteria (Gram+ bacteria and Actinobacteria) and bacteria / fungi in non-irrigated soils. Vertical bars represent the standard deviation of three replicates. Different letters indicate significant differences among treatments at the same sampling time (Tukey post hoc test, $p<0.05$ ). S: unamended soil; $\mathrm{S}+\mathrm{GC} 1$ : amended soil with green compost $1 ; \mathrm{S}+\mathrm{GC} 2$ : amended soil with green compost 2; $\mathrm{H}$ : herbicides application. The first application of herbicides is denoted by brown colour and the second application by purple colour. 

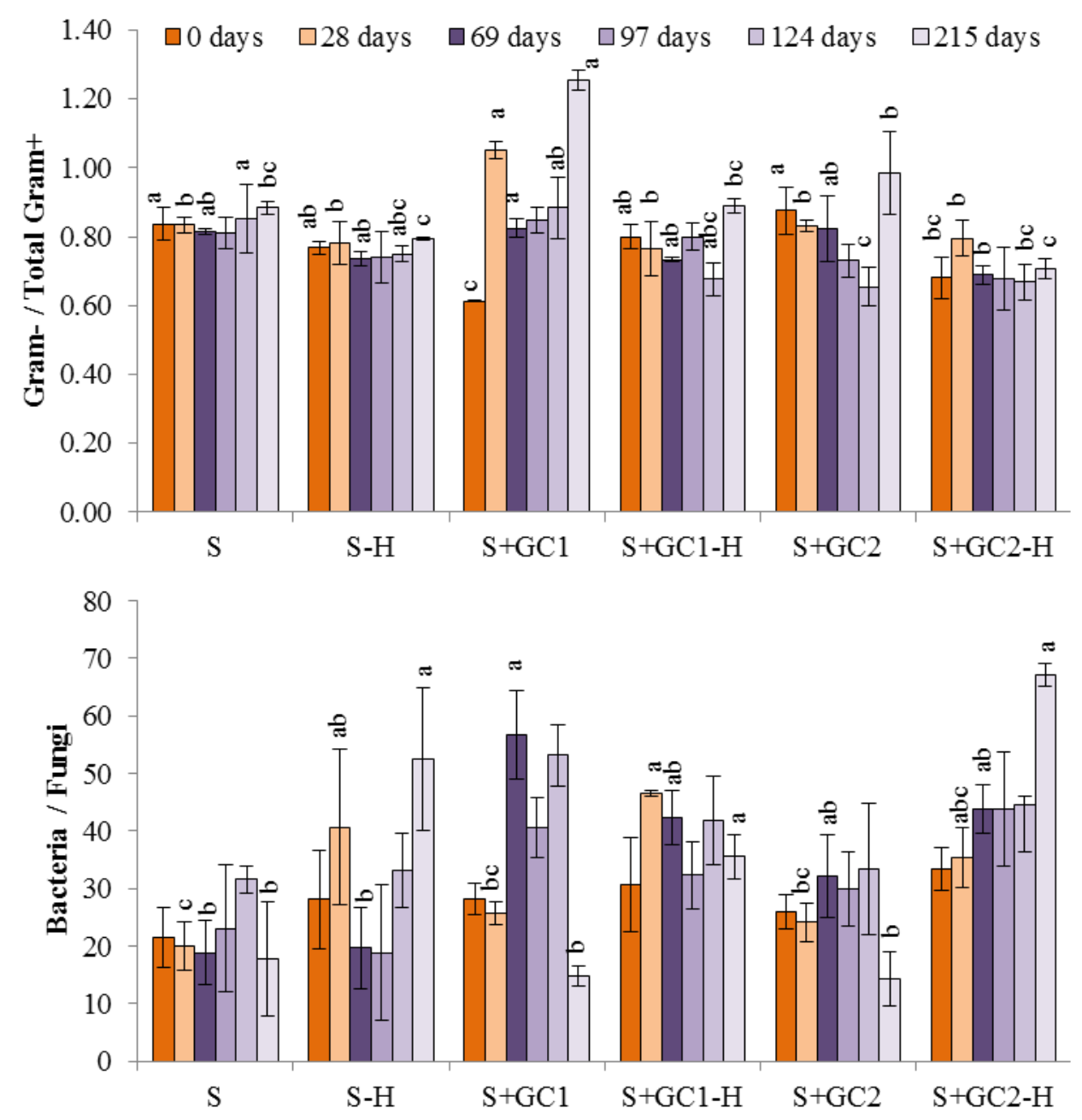

Fig S5. Ratio Gram- / total Gram+ bacteria (Gram+ bacteria and Actinobacteria) and bacteria / fungi in irrigated soils. Vertical bars represent the standard deviation of three replicates. Different letters indicate significant differences among treatments at the same sampling time (Tukey post hoc test, $p<0.05$ ). S: unamended soil; S+GC1: amended soil with green compost 1 ; $\mathrm{S}+\mathrm{GC} 2$ : amended soil with green compost 2; $\mathrm{H}$ : herbicides application; I: irrigation. The first application of herbicides is denoted by brown colour and the second application by purple colour. 


\section{Highlights}

- Agricultural practices affected herbicide dissipation and soil microbial structure.

- Repeated applications of herbicides accelerated the degradation of triasulfuron but not prosulfocarb.

- Higher content of organic matter resulted in increased herbicide residues in soils.

- Herbicides promoted the relative abundance of Actinobacteria and reduced fungi.

- The changes on soil microbiology produced by herbicides modify their degradation rates. 


\section{Graphical Abstract}

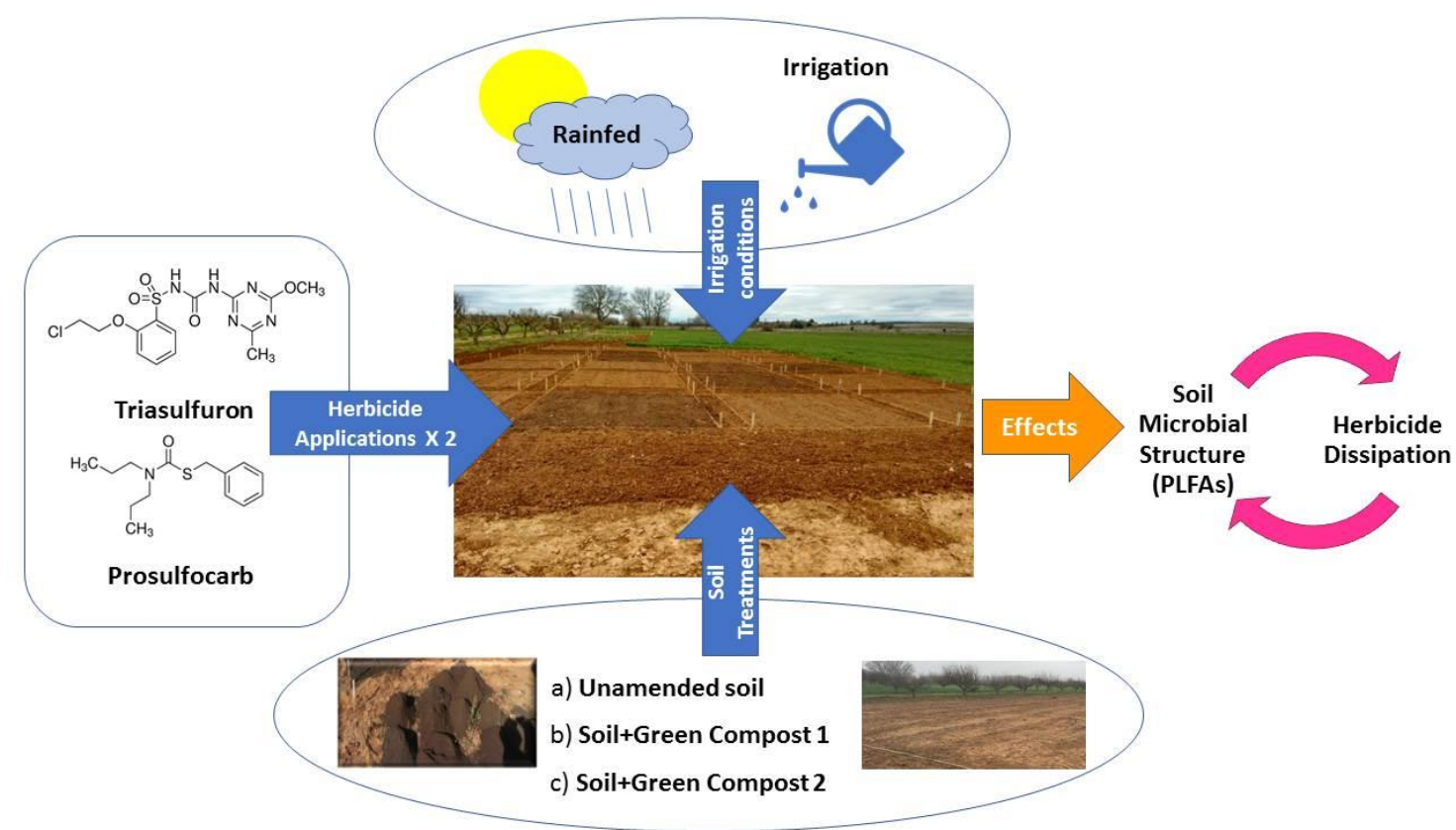

